\title{
Controls on intermontane basin filling, isolation and incision on the margin of the Puna Plateau, NW Argentina $\left(\sim 23^{\circ} \mathrm{S}\right)$
}

\author{
Rebecca L. Streit, * Douglas W. Burbank,* Manfred R. Strecker, $\uparrow$ Ricardo N. Alonso, + \\ John M. Cottle* and Andrew R.C. Kylander-Clark* \\ * Department of Earth Science, University of California, Santa Barbara, CA, USA \\ $\dagger$ Institut für Erd- und Umweltwissenschaften, Universität Potsdam, Potsdam, Germany \\ $\$$ Departamento de Geología, Universidad Nacional de Salta, Salta, Argentina
}

\begin{abstract}
Intermontane basins are illuminating stratigraphic archives of uplift, denudation and environmental conditions within the heart of actively growing mountain ranges. Commonly, however, it is difficult to determine from the sedimentary record of an individual basin whether basin formation, aggradation and dissection were controlled primarily by climatic, tectonic or lithological changes and whether these drivers were local or regional in nature. By comparing the onset of deposition, sediment-accumulation rates, incision, deformation, changes in fluvial connectivity and sediment provenance in two interrelated intermontane basins, we can identify diverse controls on basin evolution. Here, we focus on the Casa Grande basin and the adjacent Humahuaca basin along the eastern margin of the Puna Plateau in northwest Argentina. Underpinning this analysis is the robust temporal framework provided by $\mathrm{U}-\mathrm{Pb}$ geochronology of multiple volcanic ashes and our new magnetostratigraphical record in the Humahuaca basin. Between 3.8 and $0.8 \mathrm{Ma}, \sim 120 \mathrm{~m}$ of fluvial and lacustrine sediments accumulated in the Casa Grande basin as the rate of uplift of the Sierra Alta, the bounding range to its east, outpaced fluvial incision by the Río Yacoraite, which presently flows eastward across the range into the Humahuaca basin. Detrital zircon provenance analysis indicates a progressive loss of fluvial connectivity from the Casa Grande basin to the downstream Humahuaca basin between 3 and $2.1 \mathrm{Ma}$, resulting in the isolation of the Casa Grande basin from 2.1 Ma to $<1.7 \mathrm{Ma}$. This episode of basin isolation is attributed to aridification due to the uplift of the ranges to the east. Enhanced aridity decreased sediment supply to the Casa Grande basin to the point that aggradation could no longer keep pace with the rate of the surface uplift at the outlet of the basin. Synchronous events in the Casa Grande and Humahuaca basins suggest that both the initial onset of deposition above unconformities at $\sim 3.8 \mathrm{Ma}$ and the re-establishment of fluvial connectivity at $\sim 0.8 \mathrm{Ma}$ were controlled by climatic and/or tectonic changes affecting both basins. Reintegration of the fluvial network allowed subsequent incision in the Humahuaca basin to propagate upstream into the Casa Grande basin.
\end{abstract}

\section{INTRODUCTION}

In tectonically active orogens, the stratigraphic and paleoenvironmental records preserved within intermontane basins can reveal the history of uplift and erosion of nearby ranges. Unconformities, changes in sedimentaccumulation rates, variations in grain size and depositional environment, and changes in sediment provenance record both tectonic and climatic forcing (e.g. Burbank \& Raynolds, 1988; Jordan et al., 1988; Bookhagen \& Strecker, 2012). The complex relationships between these parameters typically render an unambiguous assessment of climatic vs. tectonic signals in the depositional record

Correspondence: Rebecca L. Streit, Department of Geology, College of William and Mary, P.O. Box 8795, Williamsburg, VA 23187-8795. E-mail: rljiron@wm.edu difficult. For example, in addition to directly driving changes in the sedimentary system (e.g. fluvial connectivity, exposure of erodible or resistant rocks and stream gradients), tectonics can cause fundamental climatic changes that affect the system when the surface uplift of the bounding ranges enhances the orographic precipitation on a range's windward side, while creating a rain shadow that induces a long-term shift to more arid conditions on its leeward side. Such relationships, including pronounced gradients in topography, rainfall and surface processes across the orogen, are well illustrated along many flanks of Cenozoic plateaus worldwide, (e.g. Uba et al., 2007; Strecker et al., 2009; Hough et al., 2011; Yildirim et al., 2011; Burbank et al., 2012; Lease et al., 2012; Schildgen et al., 2014), and provide insight into the characteristics of the sediment-routing system between 


\section{R.L. Streit et al.}

the orogen interior and adjacent foreland regions. In addition, if basin deposits can be chronologically constrained, such basin fills may help understand the spatiotemporal patterns of the tectonic deformation along orogenic plateau margins. The eastern margin of the Puna Plateau in Argentina, the southern sector of the intra-orogenic Andean Altiplano-Puna Plateau, is such a region where sedimentary archives are preserved in intermontane basins that are parallel to the plateau margins.

Studies of intermontane basins on the eastern margin of the Puna Plateau have provided useful constraints on Cenozoic Andean deformation, uplift of bounding ranges, tectonically driven orogen-scale climate change and more regionally limited effects of climate response to surface uplift. Variations in sediment accumulation in Andean intermontane basins straddling the Puna margin have been attributed to increasing accommodation in the footwall of active thrust faults (Coutand et al., 2006; Deeken et al., 2006; Mortimer et al., 2007), exhumation of different lithologies in the bounding ranges (Sobel \& Strecker, 2003; Deeken et al., 2006), channel defeat and basin isolation as a result of surface uplift of downstream ranges (Hilley \& Strecker, 2005; Hain et al., 2011; Bonorino \& Abascal, 2012), climatic changes (Bywater-Reyes et al., 2010) and the combination of both aridity and deformation within the basin (Starck \& Anzótegui, 2001; Strecker et al., 2009; Schoenbohm et al., 2015). Despite broad similarities among these basins, in detail, deposits within the basins straddling the eastern flanks of the Puna are diachronous, reflecting the asynchronous uplift of individual ranges spanning the Late Miocene to Pleistocene (Ramos, 1999; Strecker et al., 2009). Notably, several of these basins have experienced intermittent basin isolation or episodes of severed drainage (Hilley \& Strecker, 2005; Pingel et al., 2013).

Whether an intermontane basin experiences aggradation or incision and whether it maintains downstream fluvial connectivity or becomes hydrologically isolated depends on the balance of rock-uplift rates, a river's ability to incise its bed and sediment supply (Fig. 1). Aggradation will occur behind a rising bedrock barrier where river incision cannot keep pace with the rock-uplift rates (Fig. 1b). Nonetheless, fluvial connectivity with downstream watersheds can be maintained if the rate of aggradation equals the rate of surface uplift of the bedrock channel (i.e. rock-uplift rate minus incision rate) within the zone of uplift (Burbank et al., 1996). Otherwise, the channel is defeated and the basin will become isolated (Fig. 1c). If the uplift increases the channel steepness through the bedrock portion of the river that lies downstream of an isolated basin, eventually a knick zone may propagate upstream and breach the barrier (Fig. 1d), thereby causing aggradation to cease within the formerly isolated basin (Burbank et al., 1996; Humphrey \& Kon$\mathrm{rad}, 2000)$. Basin reintegration may also occur if the rate of aggradation increases relative to the uplift, allowing sediment to overtop the barrier (Sobel et al., 2003). (a)

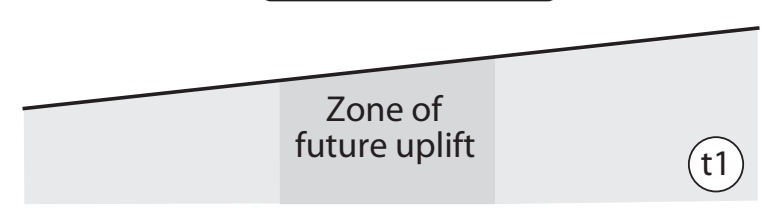

(b)

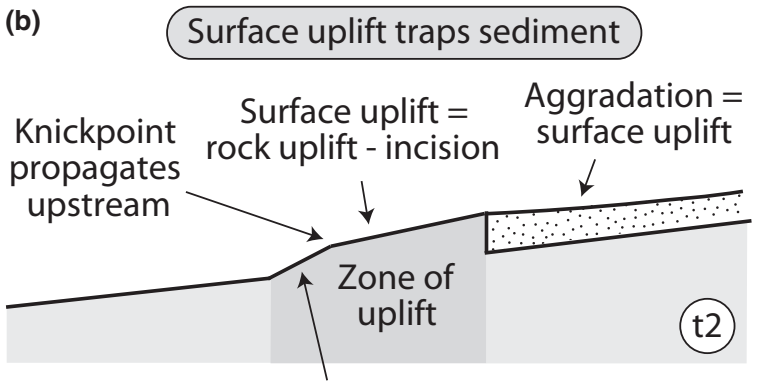

Slope adjusted so

incision $=$ rock uplift rate

(c)

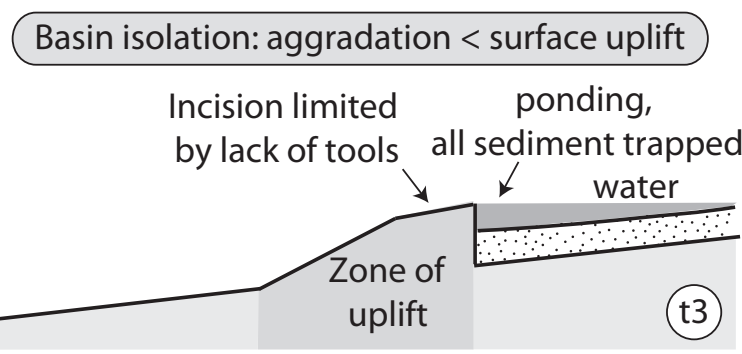

(d)

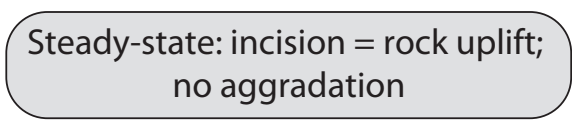

knickpoint has propagated through entire zone of uplift Aggradation

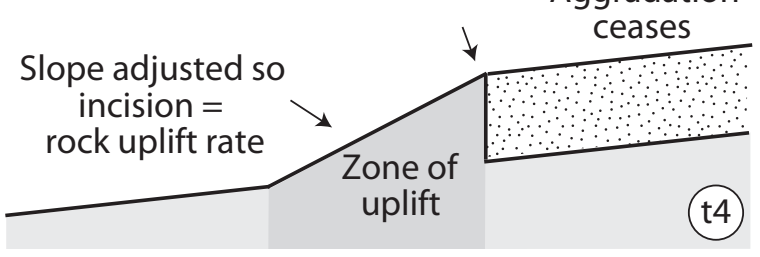

Fig. 1. Controls on sediment accumulation behind an uplifting barrier. (a) Initial channel profile, (b) Rock-uplift rate increases in zone of uplift (e.g. due to faulting). In the unadjusted portion of the channel, the river continues to incise at the initial rate, resulting in surface uplift of the channel. Upstream of the uplift, the river aggrades at a rate equal to the surface uplift at the upstream end of the zone of uplift. Uplift results in channel steepening and a knickpoint propagates upstream. Downstream of the knickpoint, the channel slope is adjusted to the new uplift rate. (c) If aggradation upstream of the zone of uplift is unable to keep pace with the rate of surface uplift, the channel is defeated, ponding occurs behind the uplift, and no sediment is transported out of the upstream basin. (d) Eventually, the knickpoint propagates all the way through the zone of uplift and the rate of rock uplift is once again balanced by the rate of incision along the entire profile. As a result, aggradation ceases in the upstream basin. 
This study focuses on the role of these processes in the evolution of the Casa Grande basin, a Plio-Pleistocene intermontane basin on the eastern margin of the Puna Plateau at $\sim 23^{\circ} \mathrm{S}$ latitude (Fig. 2). New U-Pb geochronology of numerous volcanic ashes contained within the strata throughout this region combined with an unambiguous magnetostratigraphical record provide exceptional control on the timing of the events within the Casa Grande basin and the adjacent Humahuaca basin, which is located directly downstream (Fig. 3). Both basins are connected by the narrow bedrock gorge of the Río Yacoraite, which traverses the Sierra Alta. In turn, the north-south oriented Humahuaca basin drains southward into the broken foreland. Comparison of the timing of the episodes of filling, changes in provenance and sediment-accumulation rates, and incision in each basin allows us to infer how the interplay between tectonic and climatic processes may have controlled these events. In addition, the history of fluvial connectivity between the Casa Grande and the Humahuaca basins is recorded by the zircon provenance of sedimentary deposits in the $\mathrm{Hu}-$ mahuaca basin. We find that, although the tectonic uplift of the range bounding the downstream margin of the Casa Grande intermontane basin was essential for its filling, both the onset of deposition above a basal unconformity and the loss of fluvial connectivity between the Casa Grande basin and the Humahuaca basin can likely be attributed to changes in sediment supply to the basin.

\section{GEOLOGIC SETTING}

The southern central Andes are divided into several morphotectonic provinces (Fig. 2): the Western Cordillera, which comprises the modern volcanic arc, the low-relief Altiplano-Puna Plateau to its east, the high-relief, reverse-faulted Eastern Cordillera, the thin-skinned $\mathrm{Su}-$ bandean fold-and-thrust belt, and the basement-cored uplifts of the Santa Barbara System and Sierras Pampeanas in the broken foreland (Jordan et al., 1983). The Puna Plateau has an average elevation of $\sim 4400 \mathrm{~m}$ and consists of internally drained, partially coalesced basins with intervening reverse fault-bounded ranges up to 5000-6000 m high (Turner \& Méndez, 1979; Whitman et al., 1996). Intermontane basins within the Eastern Cordillera and northern Sierra Pampeanas are structurally similar, but were only transiently isolated from the foreland during their development in late Miocene to Pleistocene time (Strecker et al., 1989, 2007; Bossi et al., 2001; Carrapa et al., 2008; Bonorino \& Abascal, 2012; Pingel et al., 2013).

Located on the eastern margin of the Puna Plateau and lying at the southern end of the Tres Cruces basin, the Casa Grande basin (Fig. 3) is bounded by the Sierra Aguilar to the west and the Sierra Alta to the east. The basin lies at an elevation of $\sim 3500 \mathrm{~m}$, but is not considered part of the Puna Plateau because it is externally drained. Within the Casa Grande basin, the Río Yacoraite flows

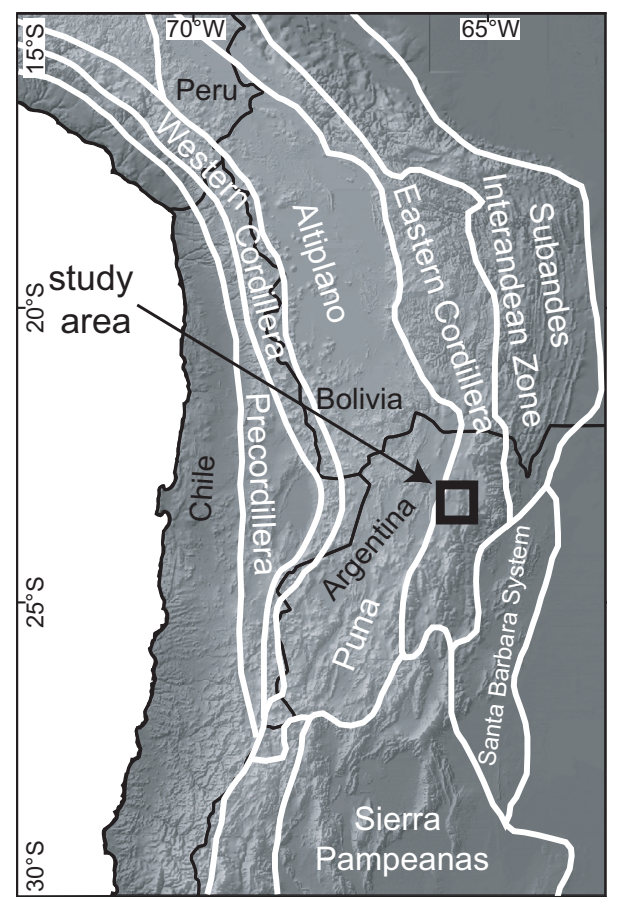

Fig. 2. Location of study area in relation of Andean morphotectonic provinces (Jordan et al., 1983; Strecker et al., 2007).

southward and exits the basin at its south-eastern end through a bedrock gorge. From there, the Río Yacoraite flows eastward through the Sierra Alta into the Quebrada de Humahuaca (Humahuaca basin), where it joins the Río Grande. The Humahuaca basin is now a long narrow valley within the Eastern Cordillera bounded by the Sierra Alta to the west and the Tilcara ranges and Sierra Hornocal to the east. The northern portion of the basin lies at an elevation of $\sim 2500-3000 \mathrm{~m}$, whereas the bounding ranges exceed $5000 \mathrm{~m}$ above sea level. The Río Grande trunk stream flows southward along the axis of the valley and exits the basin into the foreland $\sim 90 \mathrm{~km}$ south of the town of Humahuaca.

Uplift along the bivergent thrust- and reverse-fault system of the Sierra Alta and the primarily east-vergent thrust faults of the Tilcara ranges exposes Neoproterozoic to Eocene rocks (Fig. 4) (Rodríguez Fernández et al., 1999; Gonzalez et al., 2004). The most abundant units exposed are the Neoproterozoic to lower Cambrian shales, slates and phyllites of the Puncoviscana Formation, and the unconformably overlying Cambrian shelfal quartzites of the Mesón Group (Turner, 1960; Turner \& Mon, 1979). The Mesón Group is overlain by the marine sandstones and shales of the Ordovician Santa Victoria Group (Turner, 1960). Lying above a major unconformity, the Cretaceous - Paleogene Salta Group includes the Cretaceous rift-related red sandstones of the Pirgua Subgroup, the Late Cretaceous - Paleocene post-rift Balbuena Subgroup (most notably the yellow-weathering marine carbonates of the Yacoraite Formation), and the fluvial and lacustrine mudstones, siltstones and sandstones of the upper Paleocene to middle Eocene Santa Bárbara Subgroup, which have been interpreted as belonging to either 


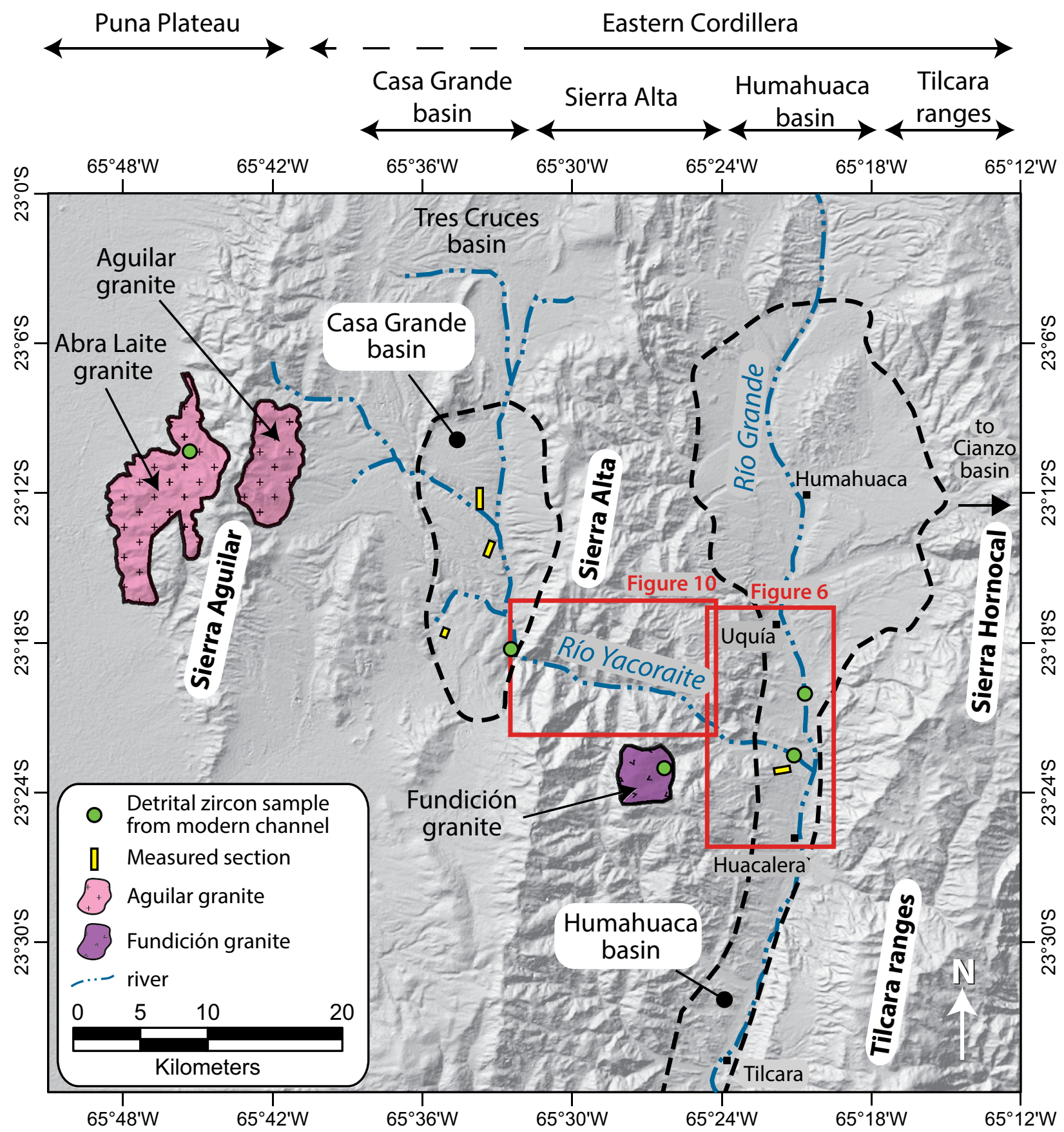

Fig. 3. Study area, with locations of the Casa Grande basin and the Humahuaca basin (dashed outlines), mountain ranges (Sierra Aguilar, Sierra Alta, Tilcara ranges and Sierra Hornocal), outcrops of granites important for provenance analysis (pink and purple shading), measured sections (yellow rectangles) and detrital zircon samples from modern channels (green circles).

thermal-subsidence basins (Moreno, 1970) or foreland basins (DeCelles et al., 2011). Late Jurassic - early Cretaceous plutons (Figs 3 and 4) (Zappettini, 1989; Cristiani et al., 2005; Insel et al., 2012) within the Sierra Alta (Fundición granite) and Sierra Aguilar (Abra Laite and Aguilar granites) provide an important signature of source areas in these ranges for our provenance analysis. Hereafter, we refer to the Abra Laite and Aguilar granites collectively as the 'Aguilar granite' because their close proximity and indistinguishable $\mathrm{U}-\mathrm{Pb}$ zircon ages, $153 \pm 4 \mathrm{Ma}$ and $150.4 \pm 0.9 \mathrm{Ma}$, respectively (Cristiani et al., 2005; Insel et al., 2012), allow them to be treated as a single source of detrital zircons for provenance analysis.

In the Casa Grande basin, the Santa Bárbara Subgroup is overlain by the upper Eo-Oligocene alluvial strata of the Casa Grande Formation (Boll \& Hernández, 1986). A prominent angular unconformity separates the Casa Grande Formation from the overlying Plio-Pleistocene intermontane basin fill which is the focus of this study. In the Humahuaca basin, the upper Miocene - Pliocene sandstones and conglomerates of the Maimará Formation were deposited in an unrestricted foreland basin setting 


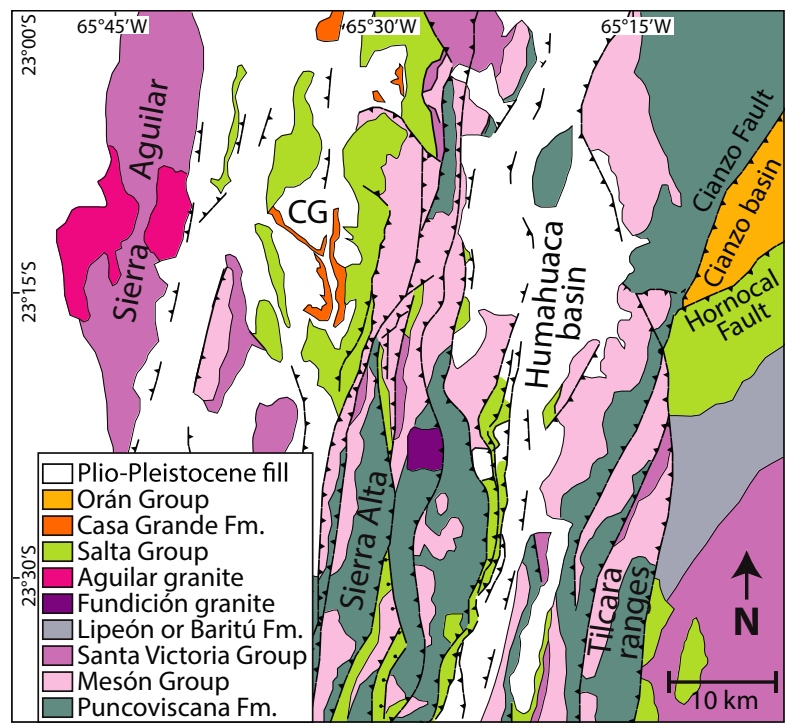

Fig. 4. Simplified geological map after Gonzalez et al. (2004). $\mathrm{CG}=$ Casa Grande basin.

(Salfity et al., 1984; Gabaldón et al., 1998; Pingel et al., 2013). The Maimará Formation is overlain by the PlioPleistocene intermontane basin deposits of the Uquía Formation in the northern portion of the basin and the Tilcara Formation in the southern portion of the basin (Marshall et al., 1982; Pingel et al., 2013). In the sections below, we present a more refined analysis of this PlioPleistocene stratigraphy.

Within the context of the overall tectonic evolution of the southern central Andes, the Plio-Pleistocene intermontane basin fills of the Casa Grande and Humahuaca basins represent a response to a phase of hinterland-stepping deformation. Shortening commenced along the western flank of the Andes $\sim 60-40 \mathrm{Ma}$ and moved into the Eastern Cordillera $40 \mathrm{Ma}$ (Horton, 2005; Hongn et al., 2007; Jordan et al., 2007; Carrapa \& DeCelles, 2015). Deformation in the Bolivian Eastern Cordillera continued until $\sim 10 \mathrm{Ma}$ (Gubbels et al., 1993) and shifted to the Subandes $\sim 12-9 \mathrm{Ma}$ (Echavarria et al., 2003; Uba et al., 2009). Farther south, at $\sim 25^{\circ} \mathrm{S}$ latitude, deformation in the Santa Barbara System began around $10 \mathrm{Ma}$ and was coeval with uplift in the western sectors of the Eastern Cordillera, but most of the deformation in the Santa Barbara System occurred $<4 \mathrm{Ma}$ (Hain et al., 2011; Pearson et al., 2013). Shortening lasted until $<4 \mathrm{Ma}$ in the Puna Plateau and has continued into the Quaternary in the Eastern Cordillera (Salfity et al., 1984; Marrett et al., 1994; Marrett \& Strecker, 2000; Sancho et al., 2008). Although paleo-elevation data for the Puna Plateau remain scarce, the uplift of ranges in the present-day sectors of the western Puna is inferred to have occurred $>38 \mathrm{Ma}$ and present-day elevations of the southern plateau margin are argued to have persisted since at least $9 \mathrm{Ma}$ (Carrapa et al., 2006, 2014; Canavan et al., 2014; Montero-López et al., 2014; Quade et al., 2015). Despite the overall west-to-east propagation of deformation, in detail, this propagation was unsteady and out-of-sequence deformation was common (Rodríguez Fernández et al., 1999; Echavarria et al., 2003; Elger et al., 2005; Mortimer et al., 2007; Strecker et al., 2009; Uba et al., 2009; Carrapa \& DeCelles, 2015).

In the Tres Cruces basin (Fig. 3), evidence of synsedimentary thrusting is recorded by upper Eocene and lower Oligocene stratal thickening in the footwall of major thrusts (Coutand et al., 2001). Oligocene deformation is also recorded by rapid exhumation and cooling $\left(\sim 5^{\circ} \mathrm{C} \mathrm{Myr}^{-1}\right)$ in the Sierra Aguilar 34-25 Ma (Insel et al., 2012). Exhumation in the Sierra Alta is recorded by mid-Miocene ( $14 \mathrm{Ma})$ apatite fission-track cooling ages from the Fundición granite (Deeken et al., 2005). In addition, Siks \& Horton (2011) interpreted the early Oligocene to middle Miocene (by $\sim 12 \mathrm{Ma}$ ) loss of western detrital zircon sources in the Cianzo basin, located within the Sierra Hornocal, east of the town of Humahuaca (Fig. 3), to reflect growing topography in the westernmost Eastern Cordillera, e.g. the Sierra Alta. The Cianzo thrust and Hornocal fault (Fig. 4) were active in the middle to late Miocene (Siks \& Horton, 2011). It is unknown whether the thrust faults within the Tilcara ranges to the east of the Humahuaca basin were also active at this time, but any surface uplift of the Tilcara ranges was insufficient to interrupt fluvial connectivity with the foreland before 4.2 Ma (Pingel et al., 2013).

A second generation of thrusting in the Eastern Cordillera - including thrusting within the Humahuaca basin - developed between $8.5 \mathrm{Ma}$ and the present day (Rodríguez Fernández et al., 1999; Sancho et al., 2008; Pingel et al., 2013). East of the Humahuaca basin, uplift of the Tilcara ranges formed a topographical barrier to the eastward flow of the fluvial system into the foreland $\sim 4.2 \mathrm{Ma}$, when the Río Grande was deflected southward (Pingel et al., 2013; Amidon et al., 2015). In addition, Pingel et al. (2014) interpret hydrogen isotope ratios of hydrated volcanic glass $\left(\delta \mathrm{D}_{\mathrm{g}}\right)$ from the Humahuaca basin to reflect surface uplift of the basin between 6.0 and $3.5 \mathrm{Ma}$.

Today the Casa Grande and Humahuaca basins have a semi-arid to arid climate, receiving $<250 \mathrm{~mm} \mathrm{year}^{-1}$ of rainfall over most of their area (e.g. Bookhagen \& Strecker, 2012). In contrast, the humid foreland east of the Tilcara ranges receives $>1000 \mathrm{~mm}_{\text {year }}{ }^{-1}$ of precipitation (Bookhagen \& Strecker, 2008), resulting in pronounced surface-process gradients (Bookhagen \& Strecker, 2012). High precipitation on the eastern flanks of the southern central Andes is attributed to the transport of moisture from the Amazon Basin by the South American Low Level Jet (LLJ) during the summer monsoon (Vera et al., 2006). Uplift of individual ranges results in orographic rainfall on the windward side of the range, increased aridity on the leeward side and commonly pronounced erosion gradients (Kleinert \& Strecker, 2001; Coutand et al., 2006; Galewsky, 2009; Bookhagen \& Strecker, 2012; Pingel et al., 2014; Rohrmann et al., 2014). The transition to the present arid 


\section{R.L. Streit et al.}

conditions in the Humahuaca basin must have occurred sometime after $\sim 3 \mathrm{Ma}$ because the presence of capybara and crocodile fossils in the middle unit $(\sim 3-2.5 \mathrm{Ma})$ of the Uquía Formation indicates that the Humahuaca basin was more humid at that time (Reguero et al., 2007). Furthermore, Pingel et al. (2014) attribute an abrupt deuterium enrichment in the hydrogen isotopic composition of hydrated volcanic glass between 3.5 and 2.5 $\mathrm{Ma}$ to the onset of semiarid conditions in the $\mathrm{Hu}-$ mahuaca basin as a result of the Tilcara ranges attaining threshold elevations for blocking moisture transport from the east.

\section{METHODS}

Stratigraphical analysis of three measured sections (0.1to $1-\mathrm{m}$ resolution) was used to characterize the depositional setting of the Plio-Pleistocene sediments in the Casa Grande basin (Fig. 5). U-Pb geochronology of zircons from five volcanic ashes interbedded with these strata provides a temporal framework that enables reliable correlations between the sections and defines average sediment-accumulation rates. To assess changes in provenance, conglomerate compositions were determined by counting at least 100 clasts $>1 \mathrm{~cm}$ in size within a $1-\mathrm{m}^{2}$ area. Where possible, paleocurrent directions were determined from the orientation of imbricated clasts or channel margins.

To track the degree of fluvial connectivity between the Casa Grande basin and the Humahuaca basin, an additional stratigraphical section (hereafter called the 'Río Yacoraite section') was measured through the Plio-Pleistocene strata in the Humahuaca basin near the mouth of the Río Yacoraite, and detrital zircon samples were collected at regular intervals through this section. The Río Yacoraite section was dated with magnetostratigraphy pinned by a high-resolution tephra date. Within this chronological framework, temporal changes in both undecompacted sediment-accumulation rates in the Humahuaca basin and relative changes in the amount of sediment transported from the Casa Grande basin to the Humahuaca basin were compared with sediment-accumulation rates in the Casa Grande basin.

Comparisons between the timing of events in the Casa Grande basin and the ages of unconformities and faulting events in the Humahuaca basin allow us to assess the role of tectonics and climate in controlling changes in the Casa Grande basin. Our geological mapping in Humahuaca basin documents cross-cutting relationships among Neogene-Quaternary strata, unconformities and faults (Fig. 6). The timing of deformation on individual structures is constrained by $\mathrm{U}-\mathrm{Pb}$ dating of intercalated ash layers within the faulted basin fill.

$\mathrm{The} \mathrm{U}-\mathrm{Pb}$ dates on zircons from volcanic ashes within the Plio-Pleistocene strata were obtained by laser-ablation multi-collector inductively coupled mass spectrometry (LA-MC-ICPMS), following the 'conventional' LA-IC-
PMS methods described by Cottle et al. (2012). Data reduction, including corrections for baseline, instrumental drift, mass bias, and down-hole fractionation and uncorrected age calculations, was carried out using Iolite version 2.21 (Paton et al., 2010). The 91500-reference zircon $\left(1065.4 \pm 0.6 \mathrm{Ma}{ }^{207} \mathrm{~Pb} /{ }^{206} \mathrm{~Pb}\right.$ ID-TIMS and $1062.4 \pm 0.8 \mathrm{Ma}{ }^{206} \mathrm{~Pb} /{ }^{238} \mathrm{U}$ ID-TIMS (Wiedenbeck et al., 1995)) was used to monitor and correct for mass bias, as well as $\mathrm{Pb} / \mathrm{U}$ fractionation. To monitor data accuracy, a secondary reference zircon - either 'GJ-1' $\left(601.7 \pm 1.3 \mathrm{Ma} \quad{ }^{206} \mathrm{~Pb} /{ }^{238} \mathrm{U} \quad\right.$ ID-TIMS age, $608.5 \pm 0.4 \mathrm{Ma}{ }^{207} \mathrm{~Pb} /{ }^{206} \mathrm{~Pb}$ ID-TIMS age) (Jackson et al., 2004) or 'SL-1' (563.5 $\pm 3.2 \mathrm{Ma}$ ID-TIMS age) (Gehrels et al., 2008) - was analysed once every $\sim 8$ unknowns and was mass bias- and fractionation-corrected based on the measured isotopic ratios of the primary reference zircon. To account for the external reproducibility of the secondary reference zircons, an additional 2\% uncertainty was propagated into the uncertainty on the measured ${ }^{207} \mathrm{~Pb} /{ }^{206} \mathrm{~Pb}$ ratios.

Because many of these ashes show some degree of fluvial reworking, preference was given to grains that showed no signs of rounding or abrasion and especially to zircons with glass still adhering to their surfaces to try to avoid zircons recycled from older strata. Zonation within zircon grains was imaged with a cathodoluminescence (CL) detector mounted on a scanning electron microscope (SEM) at the University of California, Santa Barbara. For each ash, 30-40 zircons were dated, each with one 19-30 $\mu \mathrm{m}$ analysis spot placed as close to the rim of each grain as possible to minimize the potential effect of older cores or protracted crystal growth.

Measured U- $\mathrm{Pb}$ ratios were corrected for initial ${ }^{230} \mathrm{Th}$ disequilibrium and common lead. The measured ${ }^{238} \mathrm{U} /{ }^{206} \mathrm{~Pb}$ and ${ }^{207} \mathrm{~Pb} /{ }^{206} \mathrm{~Pb}$ ratios for each analysis were corrected for initial ${ }^{230} \mathrm{Th}$ disequilibrium (Scharer, 1984) following the method of Crowley et al. (2007). The main source of uncertainty in the disequilibrium correction is the $\mathrm{Th} / \mathrm{U}$ ratio of the magma, which we estimated to be between 1 and 4 based on the range of values measured in glass adhering to 11 zircons from three different ashes; a value of $2.5 \pm 1.5(2 \sigma)$ was used for the calculation. The Isoplot 3.0 Excel plug-in (Ludwig, 2012) was then used to calculate the ${ }^{207} \mathrm{~Pb}$-corrected age for each analysis, using the disequilibrium-corrected ${ }^{207} \mathrm{~Pb} /{ }^{206} \mathrm{~Pb}$ and ${ }^{238} \mathrm{U} /{ }^{206} \mathrm{~Pb}$ ratios and an assumed common lead ${ }^{207} \mathrm{~Pb} /{ }^{206} \mathrm{~Pb}$ ratio of 0.836 , which is the Stacey \& Kramers bulk silicate Earth estimate at $3 \mathrm{Ma}$ (Stacey \& Kramers, 1975), with a $1 \%$ uncertainty on the assumed common lead composition. Because many of the ashes contain multiple age populations that likely reflect fluvial recycling of older ashes, as well as protracted crystal residence time in the magma chamber, we use a subset of the youngest ages to calculate the likely minimum age of each sample (Fig. 7). As a conservative estimate, the age we report for each sample is the weighted average of the five youngest analyses (excluding highly discordant analyses and analyses with large uncertainties on ${ }^{238} \mathrm{U} /{ }^{206} \mathrm{~Pb}$ or ${ }^{207} \mathrm{~Pb} /{ }^{206} \mathrm{~Pb}$ ratios), 


\section{Measured sections in the Casa Grande basin}

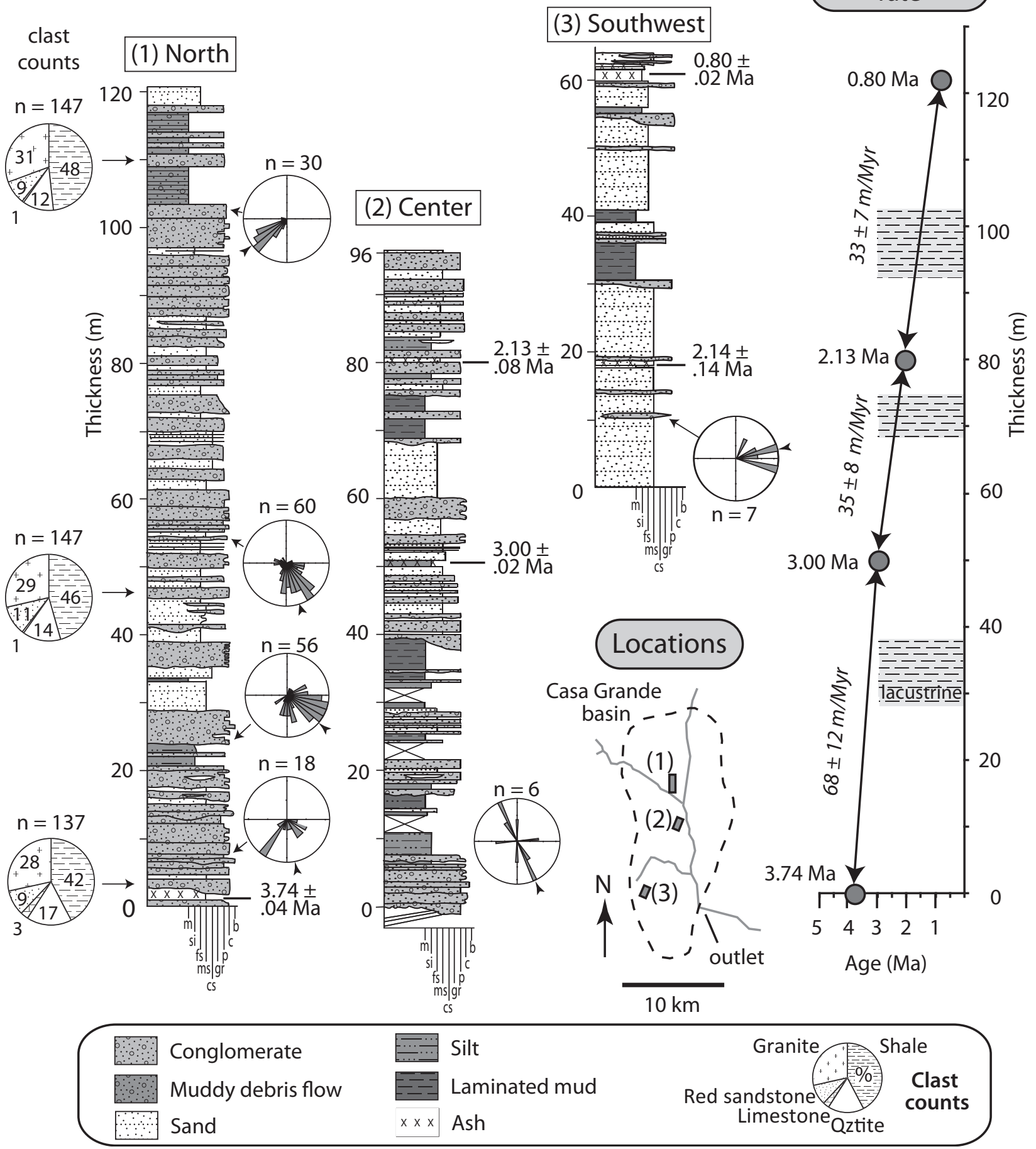

Fig. 5. Measured sections in the Casa Grande basin. Paleocurrents from imbrications (unidirectional) and channel margins (bidirectional). Ages from zircon $\mathrm{U}-\mathrm{Pb}$ geochronology of ash layers. Grain size: $\mathrm{m}$ - mud, $\mathrm{si}$ - silt, fs - fine sand, ms - medium sand, cs coarse sand, gr - granule, $\mathrm{p}$ - pebble, $\mathrm{c}$ - cobble, $\mathrm{b}$ - boulder. Average sediment-accumulation rate is given by the slope of the plot of height vs. age of ashes in measured sections. Sediment-accumulation rate decreases around 3 Ma. Light gray bars indicate intervals of lacustrine deposition within the otherwise fluvial strata.

and the uncertainty we report is two times the standard deviation of these five ages. All uncertainties are quoted at the $95 \%$ confidence or $2 \sigma$ level and include contributions from the external reproducibility of the primary reference material for the ${ }^{207} \mathrm{~Pb} /{ }^{206} \mathrm{~Pb}$ and ${ }^{206} \mathrm{~Pb} /{ }^{238} \mathrm{U}$ ratios.
Due to a paucity of volcanic ashes preserved within the Río Yacoraite section of the Humahuaca basin, we used magnetostratigraphy to date this section (Fig. 8). Where possible, three oriented block samples of siltstone, mudstone or fine sandstone were collected at intervals of 10 

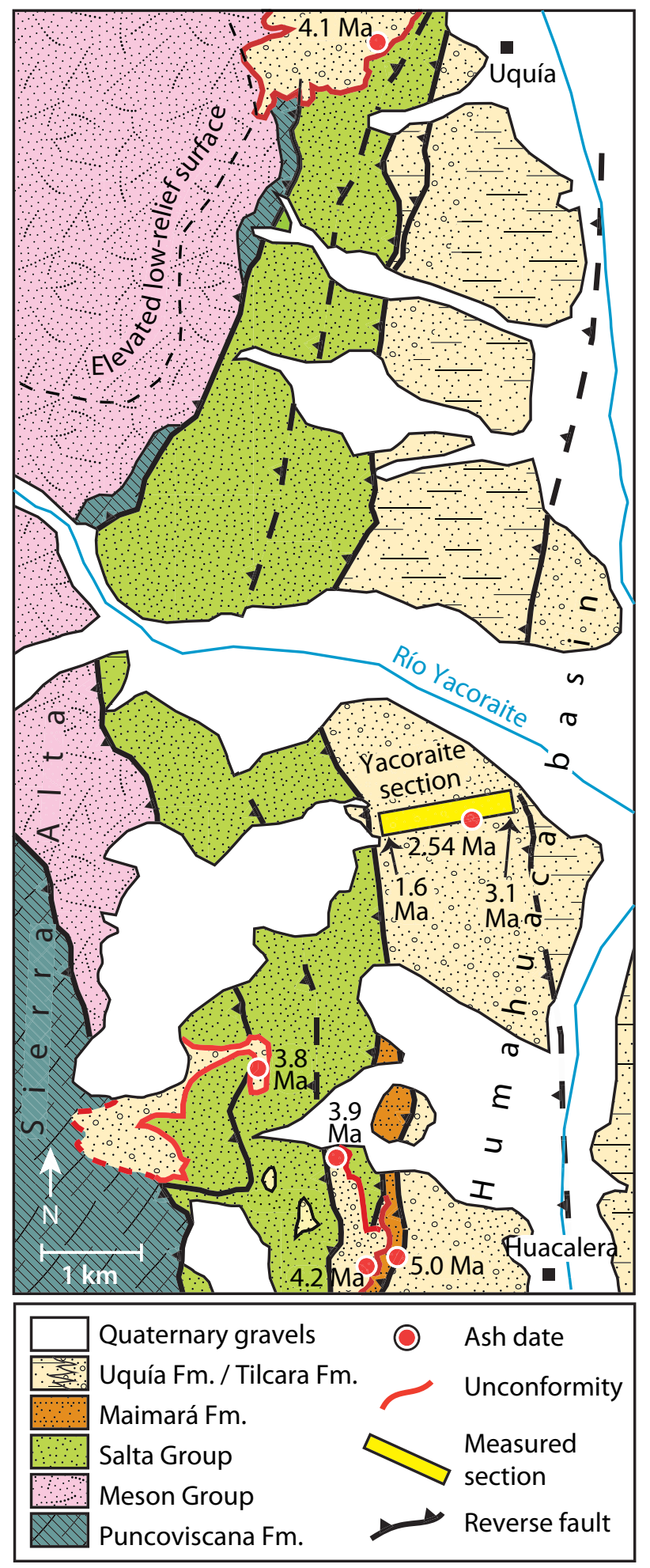

Fig. 6. The widespread unconformity in the Humahuaca basin is similar in age (4.2-3.8 Ma) to the unconformity at the base of the fill in the Casa Grande basin (3.74 Ma). Cross-cutting relationships indicate faults on the west side of the Humahuaca basin were active from $>4.3 \mathrm{Ma}$ to $<1.7 \mathrm{Ma}$. See Fig. 3 for location.

$20 \mathrm{~m}$. Measurements were performed on 2-4 specimens from each site using a DC SQUID magnetometer in the Caltech paleomagnetics lab (Kirschvink et al., 2008).

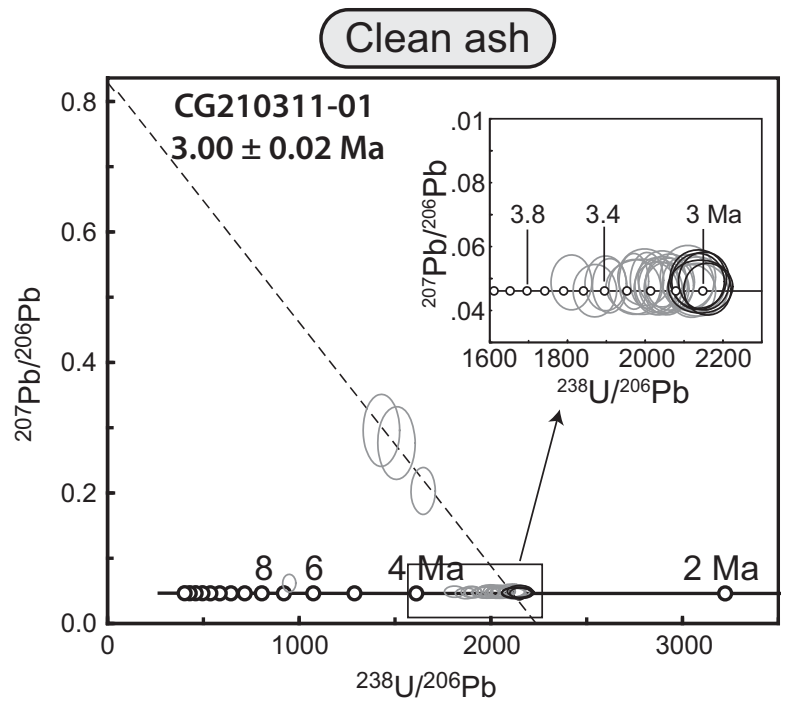

Highly reworked ash

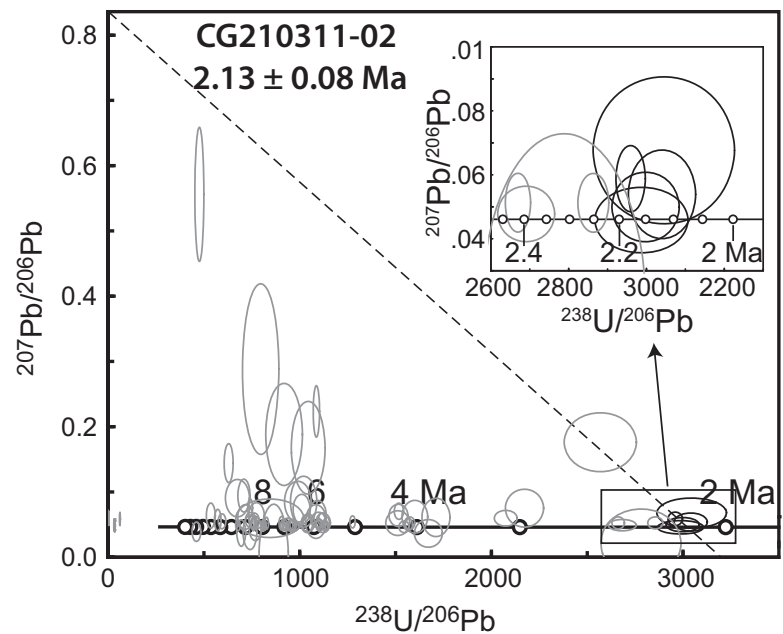

- Concordia line with ages in millions of years $2 \sigma$ Error ellipses for individual zircons:

Included in calculation of final age (youngest 5)

Excluded from calculation of final age

Fig. 7. Examples of ash data from the Casa Grande basin: a relatively pristine ash (CG210311-01, from $50 \mathrm{~m}$ in centre section) and a highly reworked ash (CG210311-02, $80 \mathrm{~m}$ in centre section). Plotted ${ }^{207} \mathrm{~Pb} /{ }^{206} \mathrm{~Pb}$ and ${ }^{238} \mathrm{U} /{ }^{206} \mathrm{~Pb}$ ratios have been corrected for initial $\mathrm{Th}$-disequilibrium using a magma $\mathrm{Th} / \mathrm{U}$ ratio of $2.5 \pm 1.5$, and then corrected for common- $\mathrm{Pb}$ using an assumed common-lead ${ }^{207} \mathrm{~Pb} /{ }^{206} \mathrm{~Pb}$ ratio of 0.836 . Ellipses show $2 \sigma$ error. The final age reported for each sample is the weighted average of the five youngest ages (black ellipses), and the uncertainty reported is two times the standard deviation of those five ages. Gray data points are excluded from the final age calculation.

After the natural remanent magnetization (NRM) was measured, specimens were cooled in liquid nitrogen to remove multidomain viscous remanent magnetism, and then subjected to stepwise thermal demagnetization in 
Fig. 8. Measured section at the mouth of the Río Yacoraite in the Humahuaca basin, including locations of detrital zircon samples and pebble clast counts. The $2.54 \mathrm{Ma}$ age is from zircon U-Pb geochronology of an ash layer at $200 \mathrm{~m}$ in the section. Grain size: as in Fig. 4. Correlation of the magnetic polarity stratigraphy to the Geomagnetic Polarity Time Scale (GPTS) (Lourens et al., 2004):

Stratigraphical log of virtual geomagnetic pole (VGP) latitudes for each specimen with mean angular deviation (MAD) $<30^{\circ}$; gray circles are specimens with $\mathrm{MAD}<15^{\circ}$ and white circles are specimens with $15^{\circ}<\mathrm{MAD}<30^{\circ}$. Normal and reversed magnetozones indicated by black and white bands, respectively, next to $\log$ of VGP latitude. Undecompacted sediment-accumulation rates are given by the slope of the plot of height vs. age of reversals and the dated ash. Error bars indicate the uncertainty in the location of reversal between normal and reversed samples.

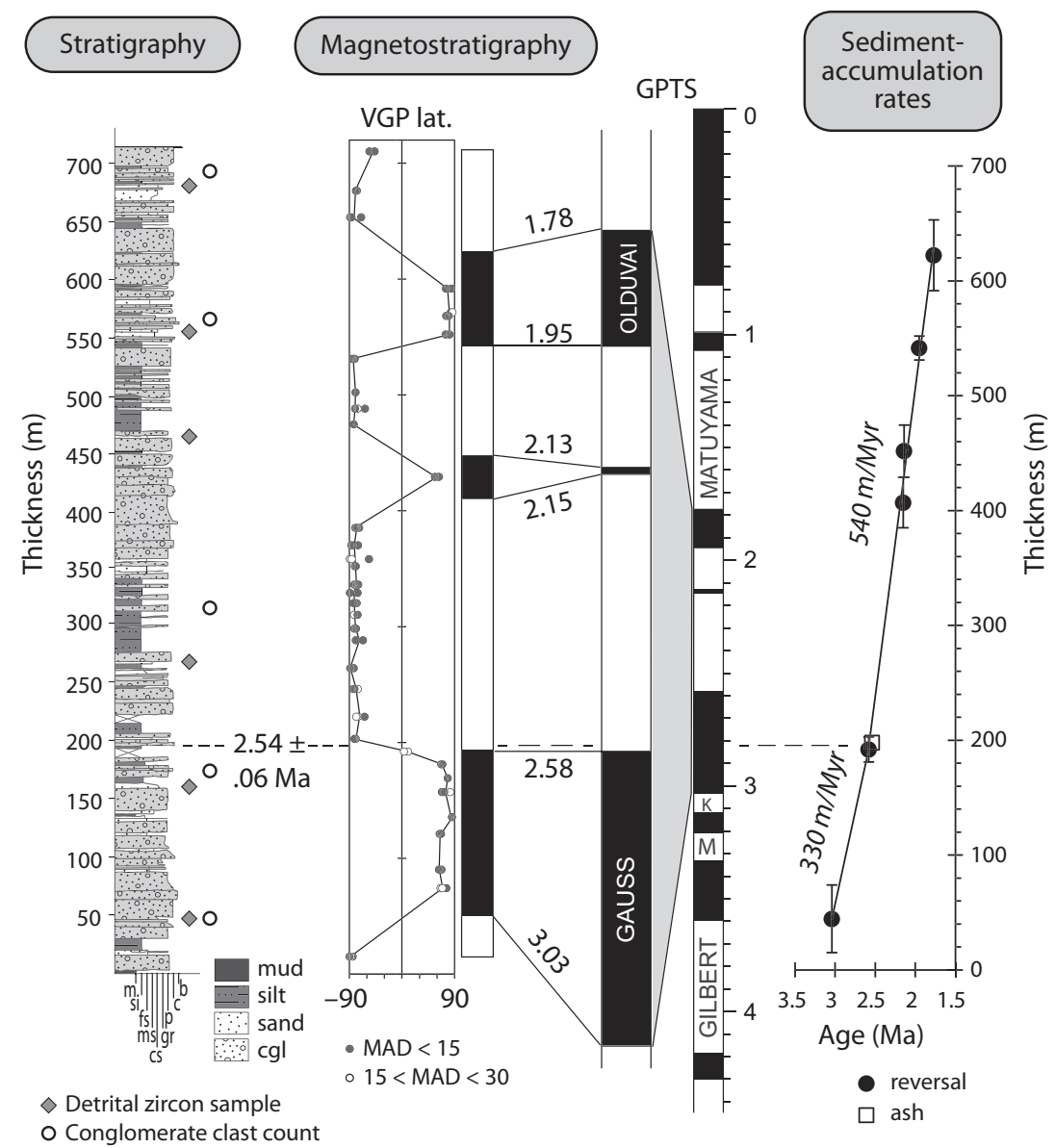

22-31 steps up to $600-690^{\circ} \mathrm{C}$ (Fig. 9a). Using PaleoMag $3.1 \mathrm{~d} 35$ (Jones, 2002), we identified the high-temperature component of the magnetization from the Zijderveld diagram (Fig. 9a) for each specimen and applied principal component analysis (Kirschvink, 1980) to at least five points (typically 10-20) to calculate the direction of each specimen's characteristic remanent magnetization (ChRM) (Fig. 9b) and its virtual geomagnetic pole (VGP). All specimens with mean angular deviations (MAD) of $\leq 15^{\circ}$ were utilized, as were 17 specimens with MADs between 15 and $30^{\circ}$ because of their consistency with adjacent specimens. The resultant VGP latitudes define magnetic polarity zones through the Río Yacoraite section which we then correlate to the Geomagnetic Polarity Timescale (GPTS) (Lourens et al., 2004) with the aid of one dated ash (Fig. 8).

The provenance of detrital zircons in the Río Yacoraite section was used to track temporal changes in the amount of sediment coming from the Casa Grande basin relative to other sources (see Fig. 3 for locations). For each sample, 200 zircon grains were dated with LA-MC-ICPMS $\mathrm{U}-\mathrm{Pb}$ geochronology. We discarded ages less than $12 \mathrm{Ma}$, because these ages are likely derived from the widespread ashes that greatly vary in abundance through time and provide little information about sediment provenance. Sediment from modern channels was used to (i) characterize the detrital zircon signatures of sediment coming from the Casa Grande basin vs. the Río Grande (the trunk stream) in the Humahuaca basin and (ii) distinguish specific source areas, such as plutons, with distinctive age signatures. Next, detrital zircon ages from mediumgrained sandstones collected at $\sim 100 \mathrm{~m}$ intervals within the Río Yacoraite section and complemented by changing conglomerate compositions were used to deduce changes in the relative contributions of different source areas. Specifically, the relative abundance of zircons from the Aguilar granite (on the eastern border of the Puna Plateau) and Fundición granite (in the Sierra Alta) was used to track the sediment flux from the Casa Grande basin over time. Potential complications to this interpretation are addressed in the results section and include the possibility that Cretaceous-Neogene strata could contain recycled zircons with ages similar to the plutons, that the areal extent of certain rock units exposed at the surface may have changed, or that drainage patterns may have changed.

Finally, topography along the Río Yacoraite was analysed to provide constraints on incision through the Sierra Alta. Elevation data were drawn from the 30-m Advanced Spaceborne Thermal Emission and Reflection Radiometer (ASTER) Global Digital Elevation Model Version 2 (GDEM V2). We used the maximum elevation across narrow swaths $(0.5-1 \mathrm{~km}$ wide) to extract the elevation profiles of ridgelines striking perpendicular to the Río Yacoraite (Fig. 10). Abrupt increases in mean slope in these profiles were identified (Fig. 10c), and the 
(a) Example demagnetization plots

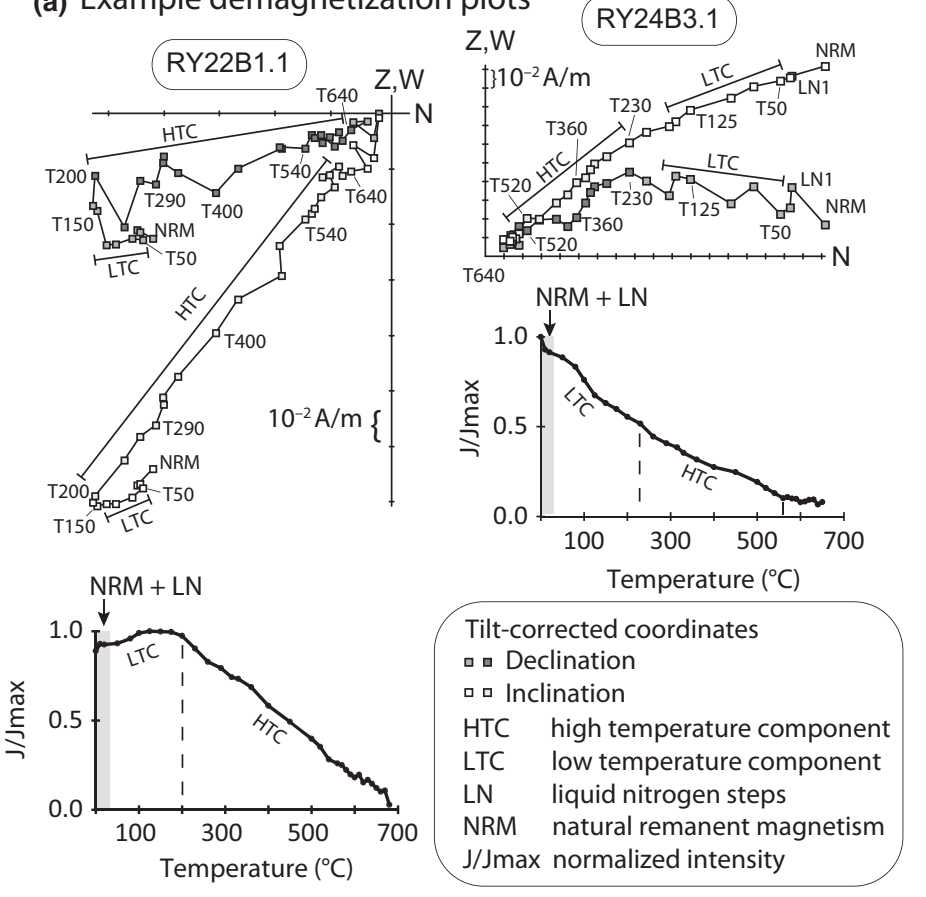

(b) Equal area plot of ChRM directions

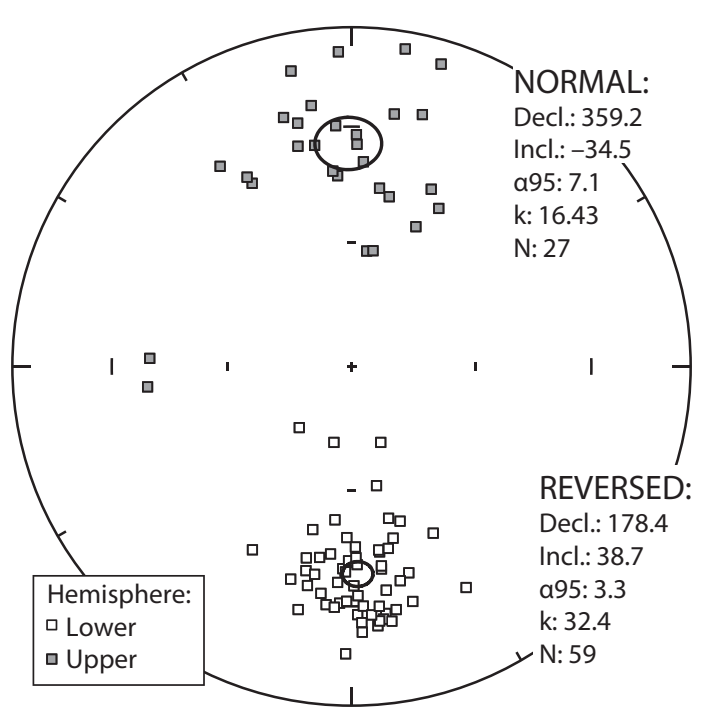

Tilt-corrected coordinates

Fig. 9. (a) Representative orthogonal demagnetization plots for specimens from the Río Yacoraite section (upper) and decay of magnetization for same specimens (lower). In orthogonal plots, darker shading indicates points used to calculate characteristic remanent magnetization (ChRM). (b) Equal-area plot of tilt-corrected ChRM directions for each specimen. Circles indicate $\alpha_{95}$ around the Fisher mean.

elevations of these slope breaks were plotted against distance downstream from the outlet of the Casa Grande basin (Fig. 10d). These slope breaks are interpreted as forming as a result of an increase in the rate of fluvial incision, causing steeper slopes adjacent to the incising river. Channels set the local base level for adjacent hillslopes, and higher incision rates produce steeper hillslope gradients, up to the threshold angle for landsliding, but the entire hillslope does not adjust instantly to the changes in incision rate (e.g. Burbank, 2002). Thus, after an increase in incision rate, the lower part of hillsides adjacent to the channel may be oversteepened, whereas their upper parts still retain the original lower slope. The height (above the channel) of the break in the slope between these contrasting regions of the hillside should be related to the amount of incision that has occurred since the increase in incision rate.

\section{RESULTS}

\section{Casa Grande stratigraphy}

In the Casa Grande basin, $120 \mathrm{~m}$ of Plio-Pleistocene fill (Fig. 5) lies above an extensive angular unconformity with the red sandstones of the Eo-Oligocene Casa Grande Formation (Boll \& Hernández, 1986). A 3-m-thick volcanic ash (CG250307-01) at the base of the fill yielded a U$\mathrm{Pb}$ zircon age of $3.74 \pm 0.04 \mathrm{Ma}$. Deposition continued until about $0.8 \mathrm{Ma}$, as indicated by a $0.80 \pm 0.02 \mathrm{Ma}$ ash (CG220311-02) lying two metres below the top of the fill in the southern measured section (Fig. 5). Since 0.8 Ma, the river has incised $>150 \mathrm{~m}$ through the Plio-Pleistocene fill and underlying Casa Grande Formation.

The basin fill consists of mostly fluvial strata with some intervals $(\sim 15 \%$ of total thickness) of lacustrine deposits (Fig. 5). Fluvial facies include clast-supported, wellsorted granule, pebble, and cobble conglomerates in the northern and centre sections and reddish siltstones and fine- to medium-grained sandstones with $10-30 \mathrm{~cm}$ horizontal beds in all three sections. The conglomerates typically display 10 - to 40 -cm-thick bedding and include thinner interbedded sandstone layers 5-10-cm-thick. Lacustrine facies consist of laminated gray to tan mudstones with occasional thin vertical rootlets in the central and southern sections. Paleoflow directions (Fig. 5) in the fluvial units inferred from measurements of channel margins and imbricated pebbles indicate average flow in the direction of the modern outlet, i.e. towards the south or south-southeast in the northern and central portion of the basin and towards the east in the southwestern portion of the basin. Downstream fining of clast size from north to south is also consistent with flow towards the present-day outlet. The northernmost section consists of pebblecobble conglomerates $(62 \%)$ interbedded with mediumto fine-grained sandstones $(25 \%)$ and with muddy debris flows (massive mudstones with matrix-supported pebbles and lenses of pebble conglomerates, $\sim 20$-cm-thick beds) $(14 \%)$ in the upper part of the section. In the centre of the basin, mostly pebble conglomerates $(38 \%)$ and sandstones $(29 \%)$ prevail with some siltstones $(8 \%)$ and a few inter- 

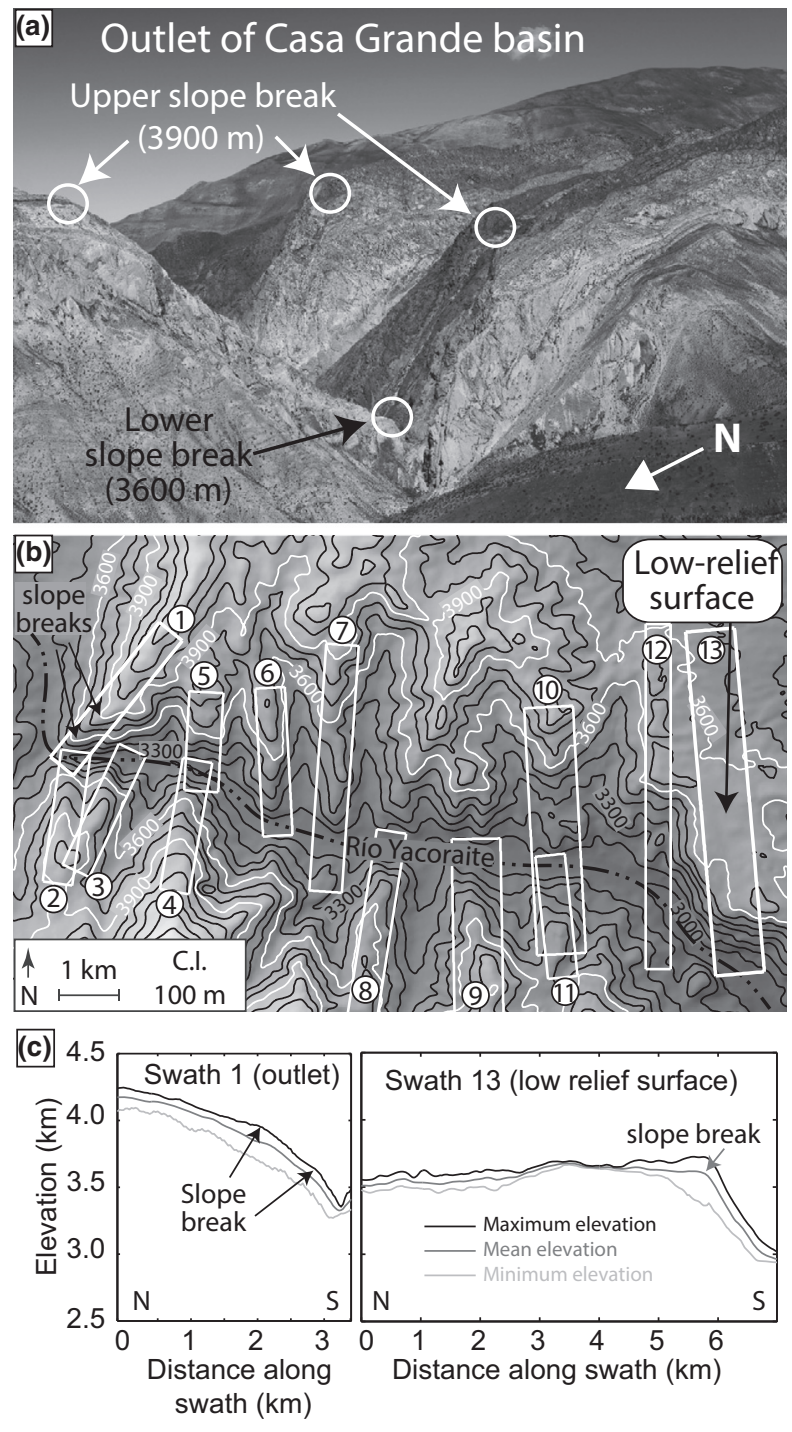

(d) Ridgeline slope breaks along Rio Yacoraite

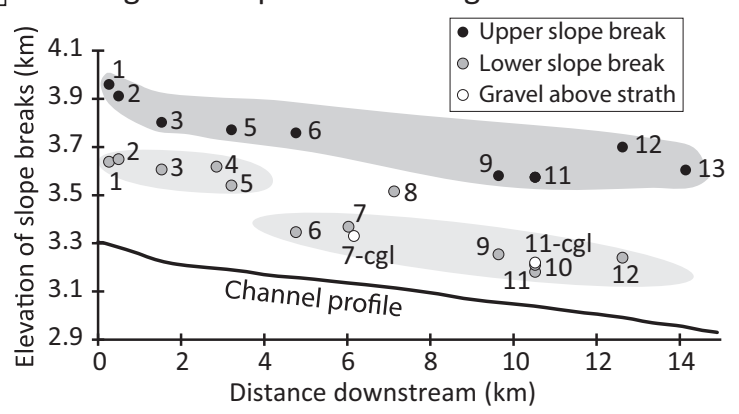

(e) Cartoon interpretation of slope breaks

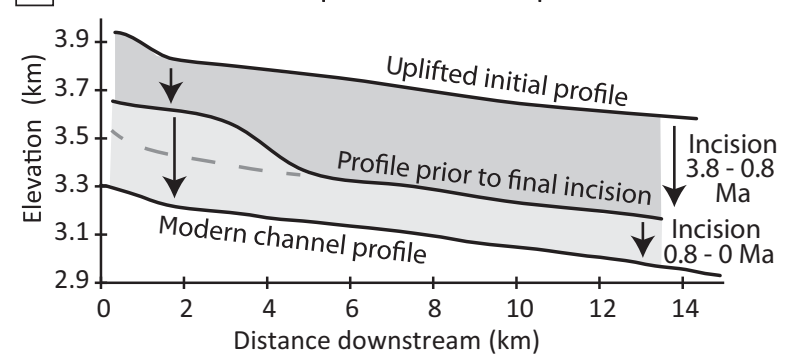

Fig. 10. Topographical indicators of surface uplift of the Sierra Alta relative to the level of the Río Yacoraite. (a) Field photo of the narrow gorge at the outlet of the Casa Grande basin, showing upper and lower breaks in slope on ridgelines striking perpendicular to the Río Yacoraite. Lower slope break is at about the same elevation as the top of the intermontane basin fill and is interpreted to have formed during the final incision after $0.8 \mathrm{Ma}$. Upper slope break is at an elevation $600 \mathrm{~m}$ above the modern river channel. (b) Topographical map of the Sierra Alta adjacent to the Río Yacoraite. White contours highlight elevations of the slope breaks at the outlet of the Casa Grande basin ( 3600 and $3900 \mathrm{~m}$ contours) and the low-relief surface on the eastern side of the Sierra Alta north of the Río Yacoraite (3600 m contour). Numbered rectangles enclose swath profiles. (c) Elevation profiles at the outlet of the Casa Grande basin and across the low-relief surface. Both the low-relief surface and the upper slope break lie $\sim 600 \mathrm{~m}$ above the modern river channel and are interpreted to be related to the onset of uplift of the Sierra Alta at $\sim 4.3 \mathrm{Ma}$. Consistent relief $(600 \mathrm{~m})$ suggests quite uniform rock uplift across the range. (d) Elevation of slope breaks on ridge crests along the Río Yacoraite and bases of gravels above small straths (7-cgl and 11-cgl). (e) Interpretation of slope breaks in relation to fluvial incision.

vals of laminated mudstones (16\%). The southern measured section is dominated by medium to fine sandstones $(78 \%)$ with intervals of laminated mudstones $(13 \%)$ and uncommon pebble conglomerates (3\%). Pebble clast counts in the northern section (taken at 2, 46 and $112 \mathrm{~m}$ in the section) demonstrate that conglomerate compositions remain fairly constant through time, consisting of $42-48 \%$ shale, $12-17 \%$ quartzite, $1-3 \%$ limestone, $9-11 \%$ red sandstone and $29-31 \%$ granitic clasts (Fig. 5).

Five new U-Pb ash ages (Fig. 5) provide a chronological framework that allows us to calculate average sediment-accumulation rates and to correlate between the measured sections and with events in the Humahuaca basin. Although three of these ashes were highly reworked and contained multiple age populations, the youngest grain ages approximate the depositional age of the sediments (Fig. 7, Table 1, Table S1). The ash at $80 \mathrm{~m}$ in the centre section (CG210311-02) and the ash at $18.5 \mathrm{~m}$ in the southern section (CG220311-01) both yielded the same age $(2.13 \pm 0.08 \mathrm{Ma}$ and $2.14 \pm 0.14 \mathrm{Ma})$, allowing robust correlation of these sections (Fig. 5). Averaged over million-year timescales, undecompacted sediment-accumulation rates decreased 50\% from $68 \pm 12 \mathrm{~m} \mathrm{Myr}^{-1}$ between 3.7 and $3.0 \mathrm{Ma}$ to $35 \pm 8 \mathrm{~m} \mathrm{Myr}^{-1}$ from 3.0 to $2.1 \mathrm{Ma}$, and then, remained at $33 \pm 7 \mathrm{~m} \mathrm{Myr}^{-1}$ until $0.8 \mathrm{Ma}$. These sediment-accumulation rates are an order of magnitude lower than sediment-accumulation rates in other intermontane basins in the Eastern Cordillera of Argentina (Bywater-Reyes et al., 2010; Schoenbohm et al., 2015) and Andean foreland basins (Reynolds et al., 2000, 2001; Echavarria et al., 2003; Horton, 2005; Uba et al., 2007; DeCelles et al., 2011; Galli et al., 2014), but are compara- 


\section{R.L. Streit et al.}

Table 1. Summary of zircon $\mathrm{U}-\mathrm{Pb}$ geochronology of volcanic ashes

\begin{tabular}{|c|c|c|c|c|c|c|}
\hline Sample & Latitude & Longitude & Description & $\mathrm{N}^{*}$ & Age† $[\mathrm{Ma}]$ & $2 \mathrm{SD} \$[\mathrm{Myr}]$ \\
\hline CG210311-01 & -23.23908 & -65.55495 & (a) $50 \mathrm{~m}$ in centre section & 30 & 3.00 & 0.02 \\
\hline CG210311-02 & -23.23965 & -65.55477 & (a) $80 \mathrm{~m}$ in centre section & 77 & 2.13 & 0.08 \\
\hline CG220311-01 & -23.29084 & -65.58504 & (a) $18.5 \mathrm{~m}$ in $\mathrm{SW}$ section & 88 & 2.14 & 0.14 \\
\hline CG220311-02 & -23.29497 & -65.58681 & (a) $62 \mathrm{~m}$ in $\mathrm{SW}$ section & 30 & 0.80 & 0.02 \\
\hline CG250307-01 & -23.22264 & -65.55517 & Base of fill, $1 \mathrm{~km} \mathrm{~S}$ of $\mathrm{N}$ section & 42 & 3.74 & 0.04 \\
\hline CG270307-02 & -23.22243 & -65.55898 & $60 \mathrm{~m}$ above CG250307-01 & 40 & 2.95 & 0.02 \\
\hline HU190412-01 & -23.41114 & -65.38380 & (a) $200 \mathrm{~m}$ in Río Yacoraite section & 30 & 2.54 & 0.06 \\
\hline UQ280307-01 & -23.30585 & -65.36925 & Above unconformity $\mathrm{W}$ of Uquía & 32 & 4.12 & 0.05 \\
\hline UQ160512-01 & -23.30218 & -65.36660 & Above unconformity $\mathrm{W}$ of Uquía & 32 & 3.97 & 0.05 \\
\hline HU240307-01 & -23.43259 & -65.37079 & Above unconformity $\mathrm{W}$ of Huacalera & 32 & 4.24 & 0.08 \\
\hline HU180411-03 & -23.43132 & -65.37006 & Above unconformity $\mathrm{W}$ of Huacalera & 30 & 4.38 & 0.11 \\
\hline HU080410-01 & -23.41936 & -65.37400 & Above unconformity $\mathrm{W}$ of Huacalera & 32 & 3.86 & 0.04 \\
\hline HU190311-01 & -23.41114 & -65.38380 & Above unconformity $\mathrm{W}$ of Huacalera & 30 & 3.80 & 0.05 \\
\hline HU210307-03 & -23.43057 & -65.36928 & Below unconformity $\mathrm{W}$ of Huacalera & 30 & 5.05 & 0.14 \\
\hline HU230412-01 & -23.41163 & -65.32528 & Fill terrace on east of Río Grande & 32 & $0.87 \S$ & 0.03 \\
\hline HU230412-02 & -23.40508 & -65.33505 & Fill terrace on east of Río Grande & 32 & 2.21 & 0.08 \\
\hline
\end{tabular}

*Number of zircons analysed.

$\dagger$ Weighted average of the five youngest ages, corrected for initial Th disequilibrium and common- $\mathrm{Pb}$.

$\$ 2 *$ standard deviation of the five youngest ages.

$\S$ Age reported for HU230412-01 only includes four youngest ages.

ble to the rates from intermontane basins in the Bolivian Eastern Cordillera (Horton, 2005). Similar to other intermontane basins in the Eastern Cordillera of Argentina (Bywater-Reyes et al., 2010; Schoenbohm et al., 2015), no clear correlation exists between the accumulation rates and average grain size within the basin.

The Plio-Pleistocene strata within the Casa Grande basin are generally flat-lying and undeformed. On the eastern side of the basin, however, the basal unconformity and overlying ash at the fill's base $\operatorname{dip} \sim 5^{\circ}$ west, suggesting differential rock uplift of the Sierra Alta range on the eastern margin of the basin. Such uplift undoubtedly influenced late Pliocene-Pleistocene sedimentary processes within the Casa Grande basin.

\section{Magnetostratigraphy \& sediment- accumulation rates in the Río Yacoraite section}

Analysis of the Río Yacoraite stratigraphical section in the Humahuaca basin (Fig. 8) illuminates changes in the amount of sediment being transported from the Casa Grande basin to the Humahuaca basin and permits comparison of the timing of deposition in the two basins. Truncated by thrust faults at the top and the base of the section, these strata comprise $715 \mathrm{~m}$ of fluvial conglomerates and siltstones dipping $\sim 10-30^{\circ}$ west. Paleoflow directions from the imbricated clasts at 45 and $174 \mathrm{~m}$ in the section indicate flow towards the east, but the relative contributions of the east-flowing Río Yacoraite and the south-flowing Río Grande (Fig. 3) likely vary throughout the section.

The Río Yacoraite section was dated with magnetostratigraphy (Fig. 8). Stepwise thermal demagnetization reveals a low-temperature component and a high-temper- ature component of NRM (Fig. 9). Whereas the lowtemperature component (interpreted as a viscous overprint) is removed by $250^{\circ} \mathrm{C}$, the high-temperature component (interpreted as the characteristic remanent magnetization: ChRM) typically decays stably towards the origin between 250 and $\sim 600^{\circ} \mathrm{C}$, although many specimens retain some remanence until $680^{\circ} \mathrm{C}$. This variable behaviour suggests that both magnetite and hematite are magnetic carriers (O'Reilly, 1984).

Following tilt corrections, the ChRM directions obtained for 88 specimens from 35 sites cluster into two antipodal groups (Fig. 9, Table 2, Table S2). Note that 17 of these 88 ChRM directions had a mean angular deviation (MAD) (Kirschvink, 1980) between $15^{\circ}$ and $30^{\circ}$, but were included in our analysis because they reveal orientations consistent with nearby 'well-behaved' specimens. These data pass a B-level reversal test (McFadden \& McElhinny, 1990), but fail the fold test, most likely due to the small variation in bedding orientations throughout

Table 2. Fisher mean of ChRM directions of normal and reversed specimens from the Río Yacoraite section and reversal test

\begin{tabular}{lcrlr}
\hline & Decl. & Incl. & $k$ & $N$ \\
\hline Geographic & & & & \\
$\quad$ Normal & 345.3 & -33.8 & 16.03 & 27 \\
$\quad$ Reversed & 160.2 & 40.7 & 30.9 & 59 \\
Tilt-corrected & & & & \\
$\quad$ Normal & 359.2 & -34.5 & 16.43 & 27 \\
$\quad$ Reversed & 18.4 & 38.7 & 32.4 & 59 \\
Reversal test (tilt-corrected) & & & \\
Difference between means: & & $4.27^{\circ}$ & \\
Critical angle (95\% confidence): & & $9.29^{\circ}$ & \\
\hline
\end{tabular}


the section (average dip is $21^{\circ}$, with a standard deviation of $6.4^{\circ}$ ).

The Río Yacoraite section's magnetic polarity stratigraphy (Fig. 8) comprises three normal and four reversed polarity zones, with each zone defined by $\geq 3$ specimens. Correlation with the Geomagnetic Polarity Timescale (Lourens et al., 2004) was aided by U-Pb dating of a $2.54 \pm 0.06 \mathrm{Ma}$ reworked volcanic ash (HU190412-01) at $200 \mathrm{~m}$ in the section. This correlation assigns an age of $3.03 \mathrm{Ma}$ (top of the Kaena subchron in the Gauss chron) to the lowest reversal at $45 \pm 30 \mathrm{~m}$ and an age of $1.78 \mathrm{Ma}$ (top of the Olduvai subchron) to the highest reversal at $622 \pm 31 \mathrm{~m}$ in the section. Assuming constant sediment-accumulation rates, the top of the section dates from $\sim 1.6 \mathrm{Ma}$.

Undecompacted sediment-accumulation rates for the Río Yacoraite section were calculated using stratigraphical thicknesses and the age of bounding magnetic polarity reversals within the section (Fig. 8). Accounting for the uncertainties in the position of reversal boundaries, the average sediment-accumulation rate of $330 \pm 90 \mathrm{~m} \mathrm{Myr}^{-1}$ from 3.03 to $2.58 \mathrm{Ma}$ increases to $\sim 540 \mathrm{~m} \mathrm{Myr}^{-1}$ from 2.58 to $1.78 \mathrm{Ma}$. The average sediment-accumulation rate between 2.58 and $1.95 \mathrm{Ma}$ (the most tightly constrained reversals) is $550 \pm$ $80 \mathrm{~m} \mathrm{Myr}^{-1}$. Although these sediment-accumulation rates are similar to the rates in other intermontane basins in Eastern Cordillera (Bossi et al., 2001; Bywater-Reyes et al., 2010; Schoenbohm et al., 2015), they are $\sim 10$-fold greater than the contemporaneous rates in the nearby Casa Grande basin $\left(\sim 30-70 \mathrm{~m} \mathrm{Myr}^{-1}\right)$. Notably, the observed changes in the rates of the two basins are asynchronous and opposite, i.e. rates decrease through time in the Casa Grande basin and increase in the $\mathrm{Hu}-$ mahuaca basin.

\section{Provenance analysis of sediment in the Río Yacoraite section}

The primary difference between the modern detrital zircon age spectra coming from the Río Yacoraite as it descends eastward from the edge of the Puna Plateau through the Sierra Alta vs. those of the Río Grande flowing southward along the axis of the Humahuaca valley is the presence or absence of a population of ages between 130 and $170 \mathrm{Ma}$ (Fig. 11b, Table S3) that typify two plutons: the Aguilar granite on the border of the Puna Plateau and the Fundición granite in the Sierra Alta (Fig. 3). Zircons from small catchments draining the Aguilar granite on the west side of the Casa Grande basin are dominated by a unique 140-155 Ma age peak (Fig. 11c, Table S3). In contrast, the Fundición granite lying between the Casa Grande basin and the Río Yacoraite section is dominated by $155-170 \mathrm{Ma}$ ages (Fig. 11c, Table S3). As expected, the modern sediment from the mouth of the Río Yacoraite contains both of these populations, whereas modern sediment from the outlet of the Casa Grande basin contains the Aguilar age population but not the Fundición age population (Fig. 11d, Table S3). Despite the similarity of these Mesozoic ages, their distinctive populations (when defined using $>150$ detrital ages) permit discrimination between (i) sediment provenance from the Casa Grande basin catchment (which contains the Aguilar granite), indicative of fluvial connectivity across the Sierra Alta and (ii) sediment provenance limited to the proximal (east) flank of the Sierra Alta where the Fundición granite is exposed.

A potential complication in interpreting the presence of these age signals as indicating sediment sourced directly from these plutons is that the Cretaceous-Neogene strata (i.e. Salta Group and Orán Group) could contain recycled zircons with similar ages. Luckily, these units do not appear to contain many zircons with ages matching our narrowly defined Aguilar and Fundición age populations (145-155 and 155-170 Ma respectively). This inference is supported by the absence of this age population in our sample from the modern Río Grande, which includes in its catchment outcrops of Salta Group and Orán Group rocks in the Sierra Hornocal. In addition, none of the detrital zircon samples from the Salta Group and Orán Group analysed by DeCelles et al. (2011) and Siks \& Horton (2011) contained more than one zircon grain with an age between 140 and $170 \mathrm{Ma}$.

Before interpreting the provenance data in terms of fluvial connectivity across the Sierra Alta, other processes that could affect the fraction of Aguilar-derived zircons in the Río Yacoraite stratigraphical section should be assessed. Because the deposits within our measured section likely result from mixing between the Río Yacoraite and the Río Grande, the relative abundance of sediment from the Casa Grande basin and the Sierra Alta also depends on the proportion of sediment delivered by the Río Grande. A relative increase in sediment from the Río Grande, due to either increasing sediment flux into that catchment or to the Río Grande migrating to the west side of the Humahuaca basin, should result in the same fractional decrease in the number of zircons from the Aguilar granite and the number of zircons from the Fundición granite. Thus, a key indicator of reduced sediment transport from the Casa Grande basin to the Humahuaca basin is a decrease in the fraction of Aguilar zircons relative to Fundición zircons. Second, a relative decrease in sediment derived from the Aguilar granite could also result from a decrease in the contribution of the Aguilar granite as a source of sediment to the Casa Grande basin. However, clast counts of conglomerates in the northern measured section in the Casa Grande basin (Fig. 5) show little temporal change in the abundance of granitic clasts $(\sim 30 \%)$, rendering this alternative hypothesis unlikely. We cannot completely rule out the possibility of either changes in the exposed area of Fundición granite or changes in the drainage patterns affecting the amount of sediment eroded from that pluton and deposited in the Río Yacoraite section. Given the relatively slow pace of erosion implied by the preservation of a $>4.3 \mathrm{Ma}$ lowrelief surface, however, it seems unlikely that very large 
Modern detrital zircon ages

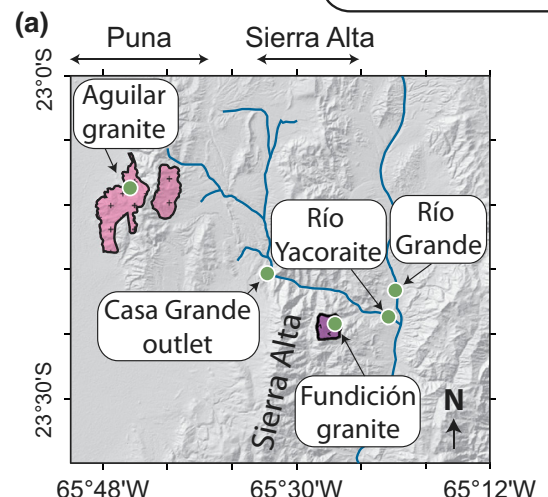

(b)
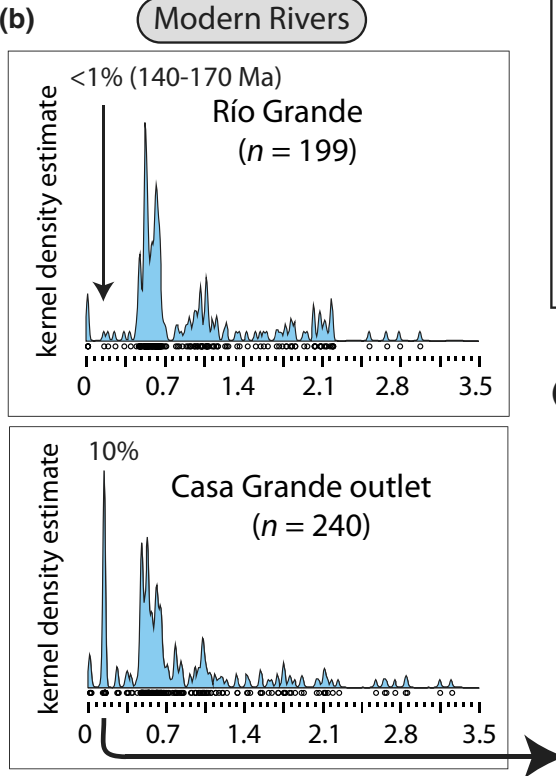

(d) Mid-Mesozoic ages

(c)
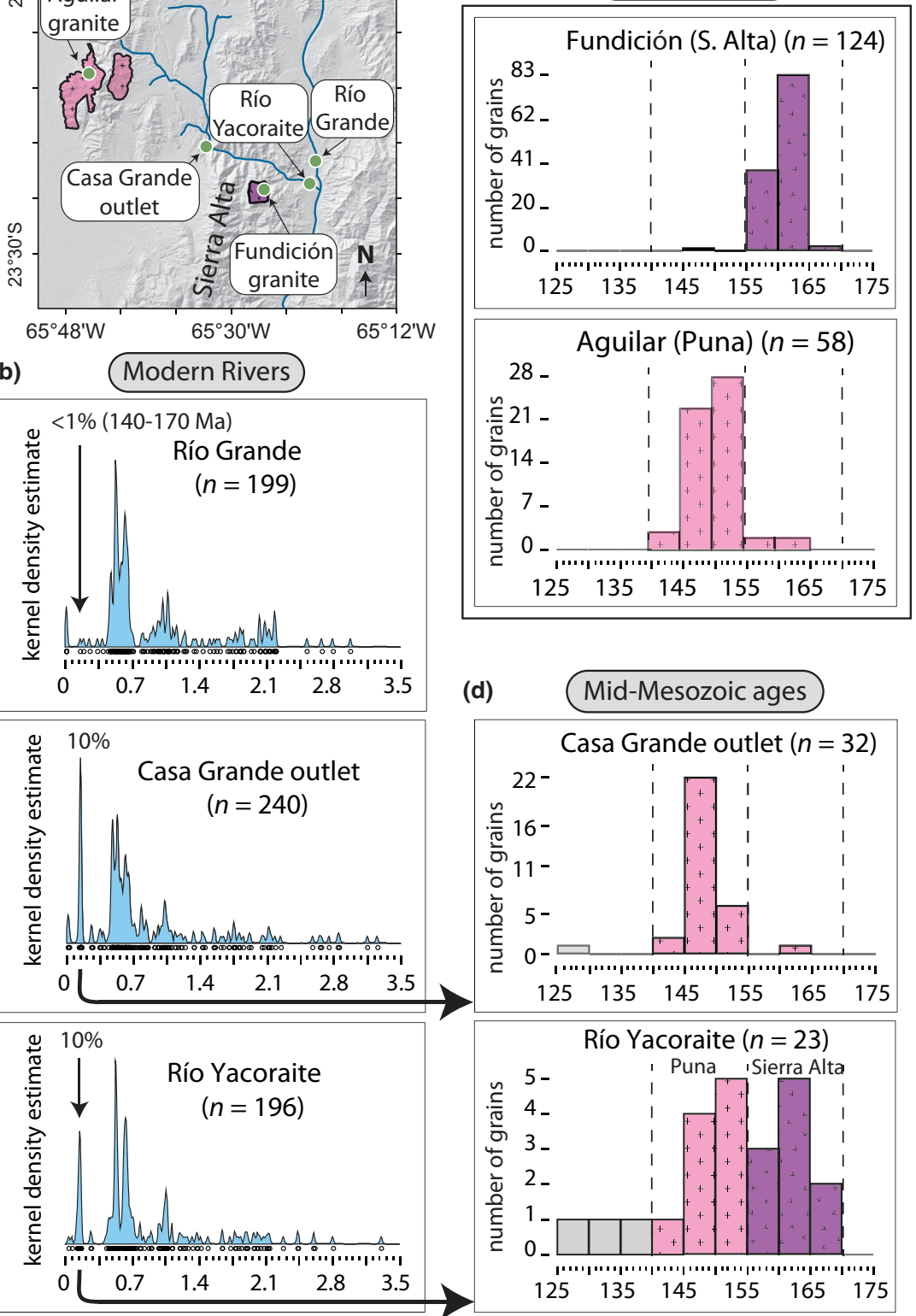

Detrital zircon age (Ga)

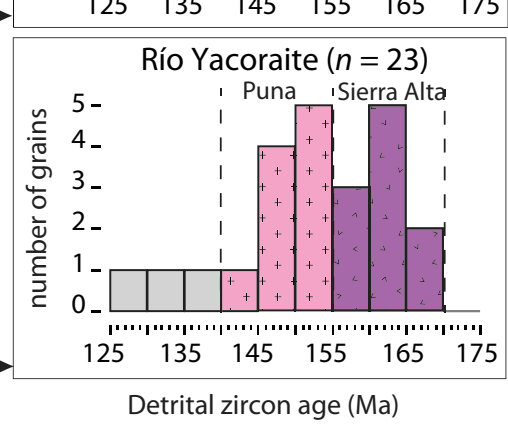

Fig. 11. Detrital zircon data from modern rivers used to characterize the signature of source areas on the border of the Puna Plateau (Aguilar granite) and Sierra Alta (Fundición granite). (a) Location of detrital zircon samples. (b) Kernel Density Estimation (KDE) plots (Vermeesch, 2012) of detrital zircon ages from: the Río Grande $6 \mathrm{~km}$ upstream of the Río Yacoraite; the outlet of the Casa Grande basin; and the Río Yacoraite $1.5 \mathrm{~km}$ upstream of the confluence with the Río Grande. $\mathrm{n}$ is the number of grains with concordant ages $>12 \mathrm{Ma}$. The samples from the Casa Grande basin and the Río Yacoraite have an age peak at $\sim 150 \mathrm{Ma}$ from the Aguilar and Fundición granites that accounts for $\sim 10 \%$ of the $>12 \mathrm{Ma}$ zircons in these samples. The Río Grande sample lacks this peak. (c) Histogram of detrital zircon ages from small catchments within the Aguilar granite or Fundición granite. Zircons from the Aguilar granite have ages between 140 and $155 \mathrm{Ma}$, whereas zircons from the Fundición granite have ages between 155 and 170 Ma. (d) Histograms of ages making up the $~ 150-$ Ma peak in the Casa Grande basin outlet and Río Yacoraite detrital zircon samples. As expected, zircons from the Casa Grande basin include the age of the Aguilar granite (Puna) but not the Fundición granite (Sierra Alta), and zircons from the Río Yacoraite include ages from both granites. changes would have occurred between 3 and 1.5 Ma. Third, the provenance data for a single sample could be biased either by short-term variability in deposition or by extreme events such as landslides. Notably, the abundance of granitic clasts in pebble-cobble conglomerates in the Río Yacoraite section follows the same decreasing trend as the fraction of detrital zircons from the Aguilar or Fundición granite (Fig. 12b). Clast counts from five sites through the Río Yacoraite section show a 10-fold decrease in the abundance of igneous clasts from $7 \%$ to $<1 \%$ between $\sim 3$ and $1.9 \mathrm{Ma}$, equivalent to 45 and $565 \mathrm{~m}$ in the section. The general agreement between these two data sets (Fig. 12) suggests that the detrital zircons are representative of long-term changes in sediment provenance.
The detrital zircon data record a decrease in the amount of sediment transported out of the Casa Grande basin and across the Sierra Alta to the Humahuaca basin between 3 and 2.1 Ma. The lowest detrital zircon sample in the measured section $(\sim 3 \mathrm{Ma})$ has a detrital age distribution similar to the modern Río Yacoraite, with the peak at $140-170 \mathrm{Ma}$ accounting for $\sim 10 \%$ of detrital zircons $>12$ Myr old and an approximately 1:1 ratio of Sierra Aguilar-derived grains (140-155 Ma) to Sierra Alta-derived grains (155-170 Ma) (Fig. 12a, Table S3). Thus, the Casa Grande basin still maintained fluvial connectivity with the Humahuaca basin at $3 \mathrm{Ma}$. From $\sim 3$ to $\sim 2.7 \mathrm{Ma}$, the fraction of Aguilar grains decreased sharply whereas the fraction of Fundición (Sierra Alta) grains remained constant. Between $\sim 2.7$ and $\sim 2.1 \mathrm{Ma}$, the relative abun- 
(a) Detrital zircons: Modern versus Plio-Pleistocene

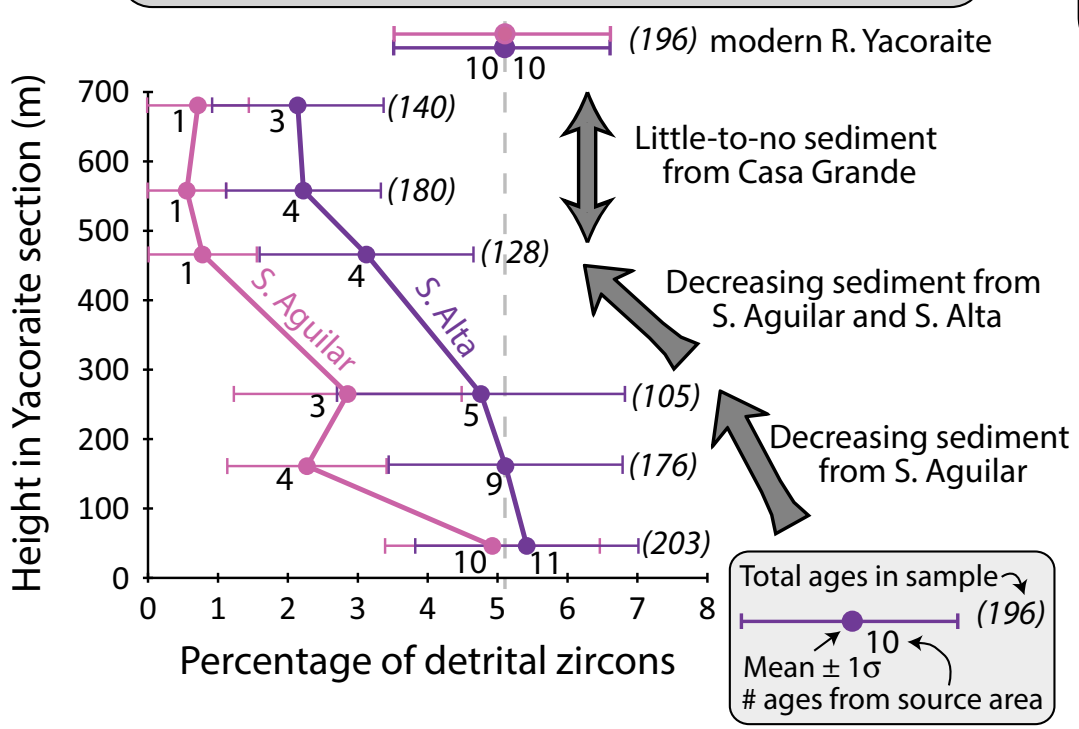

(b)
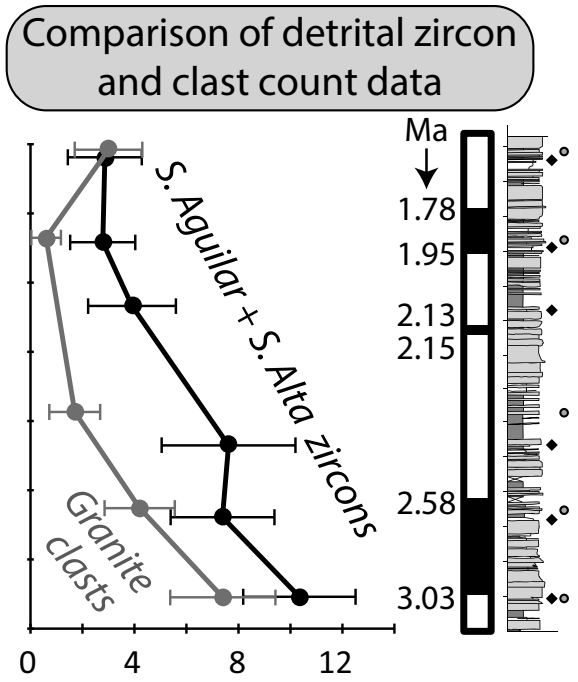

Percentage of detrital zircons

Percentage of clast count

Fig. 12. (a) Detrital zircon provenance of sediment in the Río Yacoraite section. Pink data points indicate the percentage of grains in that sample with Aguilar granite (Sierra Aguilar) ages (140-155 Ma); purple data points indicate the percentage of grains with Fundición granite (Sierra Alta) ages (155-170 Ma). The number next to each data point is the number of zircons from that source area and the number in parentheses is the number of zircons analysed with age $>12 \mathrm{Ma}$ for that sample. Above the plot, the percentages for the modern Río Yacoraite are shown for reference. (b) The percentage of granite clasts in pebble counts from the Río Yacoraite section shows the same trend as the detrital zircon data: decreasing sediment from the Sierra Aguilar and Sierra Alta relative to other sources.

dance of both Sierra Aguilar and Sierra Alta zircons decreased, and the fraction of Sierra Aguilar zircons relative to Sierra Alta zircons also decreased. Between 2.1 and 1.7 Ma, Aguilar-derived zircons accounted for $<1 \%$ of each detrital zircon sample, indicating that little or no sediment from the Casa Grande basin reached the Humahuaca basin during that time.

\section{Unconformities, incision, and deformation in the Humahuaca basin}

Comparison of the timing of the onset of deposition above unconformities and incision at the end of the filling cycle in the Casa Grande and Humahuaca basins provides insight into the tectonic and climatic conditions responsible for these events. We have identified an extensive unconformity (red lines: Fig. 6) with $\sim 4-\mathrm{Ma}$ ashes lying $<10 \mathrm{~m}$ above it at multiple locations in the northern Humahuaca basin. West of Huacalera $(5 \mathrm{~km}$ south of the Río Yacoraite), an angular unconformity separates the Maimará Formation dipping $40-45^{\circ}$ to the west from the overlying Tilcara Formation dipping $15-25^{\circ}$ to the west. Two ash samples above the unconformity (HU240307-01 and HU180411-03) yielded $\mathrm{U}-\mathrm{Pb}$ ages of $4.24 \pm$ $0.08 \mathrm{Ma}$ and $4.38 \pm 0.11 \mathrm{Ma}$, respectively, whereas an ash within the Maimará Formation $\sim 10 \mathrm{~m}$ below the unconformity yielded an age of $5.05 \pm 0.14 \mathrm{Ma}$. In this same area, the Cretaceous Pirgua Subgroup has been thrust eastward over the Maimará and lowermost Tilcara formations, and is unconformably overlain by a conglomerate with a $3.86 \pm 0.04 \mathrm{Ma}$ ash (HU080410-01) at its base. One kilometre to the west, a conglomerate with a $3.80 \pm 0.05 \mathrm{Ma}$ ash (HU190311-01) at its base unconformably overlies Salta Group rocks in the hanging wall of a younger fault that was active after $3.8 \mathrm{Ma}$. Near Uquía (8 $\mathrm{km}$ north of the Río Yacoraite), two ash layers (UQ280307-01 and UQ160512-01) in the conglomerate above an unconformity with faulted Cretaceous and Precambrian rocks were dated to $4.12 \pm 0.05 \mathrm{Ma}$ and $3.97 \pm 0.05 \mathrm{Ma}$ respectively.

Terrace abandonment and incision in the Humahuaca basin likely occurred around the same time that the filling of the Casa Grande basin ceased (after $0.8 \mathrm{Ma}$ ). The timing of Pleistocene incision in the Humahuaca basin must be younger than the $0.87 \pm 0.03 \mathrm{Ma}$ ash (HU230412-01) situated $20 \mathrm{~m}$ below the top of a $240-\mathrm{m}$-high fill terrace on the east side of the valley across from the Río Yacoraite. Lying a few metres below this $0.87-\mathrm{Ma}$ ash in the $\mathrm{Hu}-$ mahuaca basin, an unconformity truncates finer-grained siltstone and sandstone deposits (Uquía Fm.) that contain a $2.21 \pm 0.08 \mathrm{Ma}$ ash (HU230412-02). This superposition suggests that the gravel containing the $0.87-\mathrm{Ma}$ ash was deposited during a pulse of aggradation following an earlier period of erosion. The presence of an analogous 300 -m-high fill terrace $\sim 20 \mathrm{~km}$ to the south (near Tilcara: Fig. 3) with an 800-ka ash located in the lower third of the fill (Strecker et al., 2007; Pingel et al., 2013) suggests that this episode of aggradation followed by the incision in the Humahuaca basin was a significant basin-wide event.

The deformation history of the Sierra Alta provides information about potential tectonic controls on filling, 


\section{R.L. Streit et al.}

basin isolation and incision in the Casa Grande basin. Although the main phase of deformation within the Sierra Alta occurred during the Miocene (Deeken et al., 2005; Siks \& Horton, 2011), more recent deformation along the eastern edge of the Sierra Alta has been previously documented in the Humahuaca basin (Rodríguez Fernández et al., 1999; Pingel et al., 2013). We mapped several west-dipping Plio-Pleistocene reverse faults in the Humahuaca basin (Fig. 6). Slip on these faults would have promoted rock uplift of the Sierra Alta. Because these faults crosscut ash-bearing Plio-Pleistocene strata, the $\mathrm{U}-\mathrm{Pb}$ ages of the ashes serve to bracket intervals of slip along individual fault strands (Fig. 6). Reverse faults on the west side of the Humahuaca basin were active from at least $3.9 \mathrm{Ma}$, and likely from $>4.1 \mathrm{Ma}$, until $<1.6 \mathrm{Ma}$. Near the village of Uquía, the $\sim 4.1 \mathrm{Ma}$ ash above the unconformity is offset $\sim 65 \mathrm{~m}$ vertically across the fault that thrusts Paleozoic rocks over Salta Group rocks, and this same fault is sealed by the $3.8 \mathrm{Ma}$ ash above the unconformity west of Huacalera (Fig. 6). The thrust fault $\sim 2 \mathrm{~km}$ west of Huacalera with Maimara Fm. and lowermost Tilcara Fm. rocks in the footwall and Salta Group rocks in the hanging wall, must have been active between 4.2 and $3.9 \mathrm{Ma}$, based on the ages of the footwall strata and the conglomerate unconformably overlying the Salta Group rocks in the hanging wall (Fig. 6). Thrusting on the west side of the Humahuaca basin continued until $<1.6 \mathrm{Ma}$ : the age at the top of the Río Yacoraite section, which lies in the footwall of a thrust fault. Sometime after $1.8 \mathrm{Ma}$, active faulting shifted eastward to the fault in the centre of the $\mathrm{Hu}-$ mahuaca basin, as shown by the $\sim 15-45^{\circ}$ westward tilting of strata as young as $1.8 \mathrm{Ma}$ west of the Río Grande, whereas coeval strata east of the Río Grande typically dip $<10^{\circ}$ west. Thus, west-dipping reverse faults east of the Sierra Alta were active both before and during the filling of the Casa Grande basin. Other faults within the Sierra Alta may have been active during the last $4 \mathrm{Ma}$, but no cross-cutting relationships with ash-bearing NeogeneQuaternary sediments have been found.

\section{Topographic constraints on uplift and incision along the Río Yacoraite}

Topographical analysis of hillslopes flanking the Río Yacoraite provides constraints on the incision and uplift of the Sierra Alta. The ridge crest directly east of the Casa Grande basin has two abrupt breaks in slope, defining the bedrock gorge at the outlet of the Casa Grande basin (Fig. 10a, c). Similar slope breaks are observed on many ridge crests along the Río Yacoraite (Fig. 10b, d) and cluster into three groups on the basis of their heights above the modern channel: one set of upper slope breaks lie $\sim 500-700 \mathrm{~m}$ above the channel; and two sets of lower slope breaks lie $\sim 200 \mathrm{~m}$ and $\sim 300-400 \mathrm{~m}$ above the channel respectively. In addition, we observe gravels overlying small straths at two locations on the south side of the Río Yacoraite (labelled '7-cgl' and '11-cgl' on Fig. 10d). The bases of these gravels also lie $\sim 200 \mathrm{~m}$ above the modern channel. Remnants of the gravel in swath 11 can be seen as high as $350 \mathrm{~m}$ above the modern channel. Given (i) the similar heights above the modern channel of the straths along the Río Yacoraite and the unconformity between the Uquía Fm. (2.2 Ma) and the terrace fill $(0.9 \mathrm{Ma})$ on the east side of the Humahuaca basin and (ii) the thickness $(>100 \mathrm{~m})$ of the gravels in swath 11 , we suggest that the deposition of these gravels along the Río Yacoraite was coeval with the $0.9-<0.8$ Ma pulse of aggradation in the Humahuaca basin.

At the outlet of the Casa Grande basin, the higher break in slope lies $\sim 600 \mathrm{~m}$ above the modern channel. We interpret this upper slope break to reflect incision of the pre-existing topography in response to renewed rock uplift beginning $>4.1 \mathrm{Ma}$. Notably, on the eastern flank of the range, the elevated low-relief surface just north of the Río Yacoraite lies $\sim 700 \mathrm{~m}$ above the modern river (Fig. 10b, c). The similar height of the low-relief surface and upper slope breaks above the modern river implies a relatively uniform amount of uplift across the Sierra Alta, suggesting that the uplift is primarily due to the faults on the eastern side of the range rather than faulting within the range. The onlap of the $4.1 \mathrm{Ma}$ conglomerate onto the low-relief surface (Fig. 6) implies that this surface formed prior to $4.1 \mathrm{Ma}$ and was subsequently uplifted.

Whereas the height of the upper slope breaks is interpreted to indicate the total amount of incision during the Plio-Pleistocene uplift of the Sierra Alta, the lower slope breaks are interpreted to reflect an episode of rapid incision after $0.8 \mathrm{Ma}$ (Fig. 10e). At the outlet of the Casa Grande basin, this lower slope break lies $\sim 340 \mathrm{~m}$ above the modern channel, at an elevation slightly above the top of the Casa Grande basin fill. The incision below this lower slope break at the Casa Grande outlet must have occurred after $0.8 \mathrm{Ma}$, or else it would have disrupted basin filling. Lower slope breaks occur at the same height on ridge crests flanking the Río Yacoraite for $\sim 4 \mathrm{~km}$ downstream from the Casa Grande basin. Farther downstream, the lower slope break steps down to around $200 \mathrm{~m}$ above the modern channel. This contrast indicates that the upstream portion of the Río Yacoraite had not incised as much as the downstream portion prior to this final episode of incision.

\section{DISCUSSION}

\section{Reconstruction of intermontane basin history}

Evidence of Plio-Pleistocene uplift of the Sierra Alta (including thrusting on the east side of the range abutting the Humahuaca basin and tilting of basin-filling strata on the western flanks of the range in the Casa Grande basin) suggests that aggradation within the Casa Grande basin resulted when incision of the Río Yacoraite was unable to fully keep pace with rock uplift in the Sierra Alta. Fluvial connectivity with the Humahuaca basin would have been sustained as long as sediment supply was sufficient for the 
rate of aggradation to keep up with the rate of local surface uplift at the outlet (as in Fig. 1b). The Plio-Pleistocene evolution of the Casa Grande basin, therefore, depended on competition between the rate of uplift of the downstream range (Sierra Alta), the rate of incision at the basin's outlet and the rate of aggradation in the basin itself (e.g. Fig. 1); a scenario akin to the situation in the Toro basin $150 \mathrm{~km}$ to the southwest of Humahuaca (Hilley \& Strecker, 2005). In this context, events in the basin's history can be interpreted as responses to evolving tectonic, climatic and topographical conditions that affected the balances between sediment flux, transport capacity, incision, uplift, local base level and aggradation (Fig. 13). Specifically, we further explore the onset of deposition, changes in sediment-accumulation rates, basin isolation and subsequent reintegration, and final incision.

\subsection{Ma onset of deposition above an unconformity}

The initiation of deposition above an unconformity requires the sediment flux to exceed the transport capacity. A change in this ratio could result from localized or regional rock uplift or from a climate change. The synchronous onset of deposition above the unconformity in the Casa Grande and Humahuaca basins around 3.8 Ma suggests that this event was controlled by regional, rather than strictly local, conditions (Fig. 13b). Given that the uplift of the Sierra Alta was accommodated along thrust faults within the Humahuaca basin, increased uplift rates should have promoted further erosion in the hanging walls of these faults, instead of the renewed deposition above the unconformity that formed between 5 and $4 \mathrm{Ma}$. Conversely, a regional increase in rock-uplift rates in both the Sierra Alta and the Tilcara ranges, perhaps related to deeper seated structure(s) could have driven aggradation in both basins by affecting the balance between rock uplift and incision at the outlet of each basin. Increased uplift rates could also promote deposition by increasing the calibre and/or flux of sediment to the basins. Alternatively, a change in climate affecting both basins could have driven the onset of deposition above the unconformity. Although a shift to a drier climate could drive deposition by decreasing discharge and, hence, transport capacity, the shift to semi-arid conditions in the Humahuaca basin did not occur until between 3.5 and $2.5 \mathrm{Ma}$ (Reguero et al., 2007; Pingel et al., 2014). Conversely, a shift to a wetter climate or an increase in climate variability could drive deposition by increasing the sediment flux to the basin. For example, Schoenbohm et al. (2015) suggest that the onset of Punaschotter conglomerates in several basins around $4 \mathrm{Ma}$ could be related to a global increase in climate variability 4-3 Ma (e.g. Zachos et al., 2001; Lisiecki \& Raymo, 2005), which could have increased erosion rates as a result of increased landscape disequilibrium (Godard et al., 2013).

Previous studies of other basins in the Eastern Cordillera of NW Argentina (Kleinert \& Strecker, 2001; Starck \& Anzótegui, 2001; Bywater-Reyes et al., 2010; Schoenb- ohm et al., 2015) do not support a broader regional shift to more humid conditions around $4 \mathrm{Ma}$. On the other hand, a more local shift to wetter conditions as a result of localized range uplift is consistent with limited constraints on the uplift history of the Sierra Alta and Tilcara ranges. Initial uplift of a range typically results in increased precipitation due to an orographical rainfall effect and, as uplift continues, the range becomes a barrier to precipitation, leading to more arid conditions on its downwind side (Galewsky, 2009). The relationship between modern precipitation patterns (Bookhagen \& Strecker, 2012) and the elevations of ranges in the Santa Barbara System and Sierra Pampeanas indicates that ranges with elevations of 1-2 km experience increased rainfall across the entire range, whereas ranges with elevations $>2.5 \mathrm{~km}$ produce enhanced rainfall on the windward sides and a rain shadow on the leeward side. Consistent with an orographically-enhanced precipitation effect, the onset of coarsegrained deposition in the Casa Grande basin occurred during the early stages of the Plio-Pleistocene uplift of the Sierra Alta and Tilcara ranges, soon after both the $\sim 4.2$ $\mathrm{Ma}$ drainage reorganization in Humahuaca basin in response to the uplift of the Tilcara Ranges (Pingel et al., 2013) and the earliest evidence of faulting on the west side of the Humahuaca basin between 5.0 and 4.3 Ma. This interpretation implies that, despite Miocene deformation in the Sierra Alta and Sierra Hornocal (along strike with the Tilcara ranges), these ranges remained relatively low $(<2.5 \mathrm{~km})$ into Pliocene times, or that deep, E-W valleys acted as topographical conduits for moisture into the range (Barros et al., 2004). Although perhaps surprising, this interpretation is consistent with paleocurrent and provenance data from the Maimará Formation in the $\mathrm{Hu}-$ mahuaca basin, which indicate that, at $6 \mathrm{Ma}$, uplift of the Sierra Alta had not yet disrupted rivers flowing eastward from the Puna Plateau and that uplift of the Tilcara ranges did not disrupt eastward fluvial transport in the Humahuaca basin until 4.2 Ma (Pingel et al., 2013).

The onset of deposition may have been driven by a regional increase in uplift rates, a shift to more variable climate, or orographically enhanced precipitation in the early stages of range uplift. Although we cannot eliminate any of these hypotheses, we favour a tectonically driven increase in orographical precipitation, because it is consistent with constraints on the timing of Plio-Pleistocene uplift of the Sierra Alta and Tilcara ranges (Pingel et al., 2013, 2014).

\section{Rock uplift outpaces incision}

Sustained sediment accumulation in the Casa Grande basin is interpreted to have occurred when rock-uplift rates in the Sierra Alta persistently outpaced fluvial incision at the outlet of the basin. This imbalance caused local surface uplift of the bedrock channel immediately downstream of the outlet of the Casa Grande basin and drove aggradation behind this rising barrier. The increase in sediment supply relative to the transport capacity could 


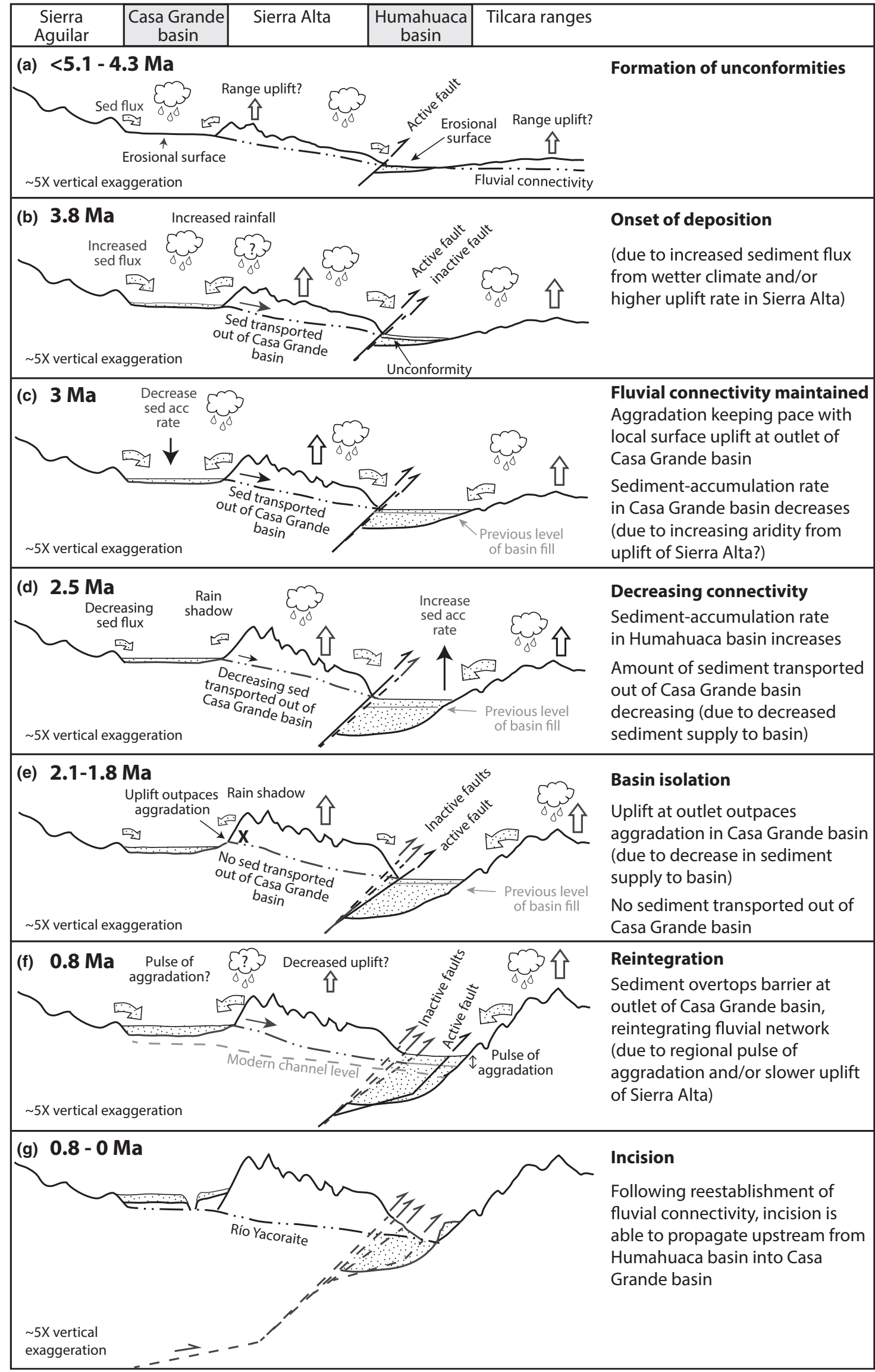

Fig. 13. Cartoon summary of Plio-Pleistocene history of the Casa Grande basin, highlighting timing and causes of events, such as the onset of deposition, changes in sediment-accumulation rates, basin isolation, reintegration of the fluvial network and final incision. 
have decreased the river's ability to incise through the uplifting Sierra Alta by increasing the fraction of the bedrock channel protected by sediment cover (e.g. Sklar \& Dietrich, 2001). This effect, however, likely would be transient: the reduction in bedrock incision due to cover would cause the channel to steepen with continued uplift, thereby resulting in a new equilibrium with both a steeper channel slope and a likely decrease in cover above the bedrock channel.

\section{Ma to 2.1 Ma loss of fluvial connectivity}

In the Río Yacoraite stratigraphical section, detrital zircons sourced from the Aguilar granite (Fig. 3) indicate persistent fluvial connectivity between the Casa Grande and downstream Humahuaca basins between 3 and 2.5 Ma (Figs 12a and 13c). Therefore, aggradation in Casa Grande basin must have approximately balanced the pace of local surface uplift at the basin's outlet (Fig. 1b). During this period, however, the relative abundance of detrital zircons of Aguilar age (140$155 \mathrm{Ma}$ ) from the Casa Grande basin catchment decreased, and by 2.1 Ma, almost no sediment from the Casa Grande basin reached the Humahuaca basin (only a single zircon with Aguilar age out of $\sim 200$ dated grains: Fig. 12).

Between 3 and 2.1 Ma, the sediment flux out of the Casa Grande basin diminished whereas the basin's sediment-accumulation rate remained constant (Fig. 5). These synchronous effects imply a long-term decrease in the amount of sediment entering the Casa Grande basin: a change that may reflect a transition to a more arid climate due to an enhanced rain shadow driven by continuing uplift of the Sierra Alta and Tilcara ranges (Figs. 13d, e). For basins with gently sloping margins, sediment-accumulation rates in a vertical stratigraphical section could remain constant while the amount of sediment transported out of the basin decreased even if the amount of sediment delivered into the basin did not decrease. For the geometry of the Casa Grande basin with its relatively wide, flat bottom and steep sides, however, this effect would be small (Table S4). Second, if only a small fraction of the sediment flux into the basin is transported out of the basin, then even a dramatic relative decrease in the amount of sediment transported out of the basin will have only a small effect on the rate of sediment accumulation in the basin.

We argue, however, that at $3 \mathrm{Ma}$, a large fraction of the sediment flux into the Casa Grande basin was likely transported out of the basin. Given that (i) the relative abundance of detrital zircons sourced from the Aguilar granite (easternmost Puna) and Fundición granite (Sierra Alta) in the Río Yacoraite section at $3 \mathrm{Ma}$ is very similar to that of modern sediment near the mouth of the Río Yacoraite and (ii) very little sediment is being trapped in the Casa Grande basin today, we infer that a significant fraction of the sediment entering the Casa Grande basin was also transported out of the basin $3 \mathrm{Ma}$. Although this conclu- sion would be invalid if the Aguilar granite accounted for a much larger fraction of sediment entering the basin in the past than today, this scenario is unsupported. The fraction of granite pebbles in $\sim 3-\mathrm{Ma}$ conglomerates in the Casa Grande basin (30\% in the northern measured section) are not dramatically different from today $(15 \%$ at the outlet of the basin), and this difference could be due to the location within the basin, rather than to the changes in the amount of granite entering the basin. Thus, having discounted these alternative explanations, we invoke a decrease in sediment supply to explain the combined observations of (i) a decrease in the amount of sediment transport out of the Casa Grande basin between 3 and $2.1 \mathrm{Ma}$ with (ii) a concurrent decrease in the sedimentaccumulation rates in the Casa Grande stratigraphical sections.

Such a decrease in sediment flux in response to increased aridity is consistent with the onset of semiarid conditions in the Humahuaca basin between 3.5 and $2.5 \mathrm{Ma}$ (Pingel et al., 2014). The $\sim 50 \%$ decrease in average sediment-accumulation rates in the Casa Grande basin during this same interval (Fig. 5) may also reflect this decrease in sediment supply. As the Casa Grande basin's sediment supply decreased, a larger fraction of that sediment was trapped in the basin by the local surface uplift at the outlet of the basin, resulting in the decrease in the abundance of Aguilar-derived zircons in the Río Yacoraite section between 3 and 2.7 Ma. By 2.1 Ma, Casa Grande's sediment flux had decreased to the point that aggradation could no longer keep pace with this uplift, resulting in a loss of fluvial connectivity with the Humahuaca basin.

\subsection{Ma to $<1.7$ Ma continued basin isolation}

From 2.1 Ma to the end of our detrital zircon record at $\sim 1.7 \mathrm{Ma}$ in the Río Yacoraite section, the Casa Grande basin remained largely isolated from the Humahuaca basin (Figs 12 and 13e). Even during this period of basin isolation, the deposits preserved within the Casa Grande basin constitute dominantly fluvial facies (Fig. 5). These facies imply that any lake that formed as a result of channel defeat at the basin's outlet was likely limited in extent to the southeastern portion of the basin near the modern outlet: a region where few Plio-Pleistocene sediments are currently preserved. Lacustrine intervals in the measured sections in the southwest and centre of the Casa Grande basin could reflect either fluctuations in the extent of that lake or the formation of separate small lakes. The presence of lacustrine facies in the centre of Casa Grande basin prior to $3 \mathrm{Ma}$ (Fig. 5) also raises the possibility of an earlier cycle of basin isolation and reintegration. However, we cannot test this scenario with detrital zircon data because dated deposits older than $\sim 3 \mathrm{Ma}$ are not known near the mouth of the Río Yacoraite in the Humahuaca basin (Fig. 8).

With little or no sediment leaving the Casa Grande basin, the segment of the Río Yacoraite immediately downstream of the basin would have lacked tools to erode 


\section{R.L. Streit et al.}

its bed, resulting in decreased incision rates (Sklar \& Dietrich, 2001). Farther downstream, sediment eroded from the Sierra Alta would have provided tools to maintain higher incision rates. This contrast could have resulted in the greater incision of the downstream portion of the Río Yacoraite prior to $0.8 \mathrm{Ma}$ and the development of a 150 m-high knickpoint, as inferred from the height of slope breaks along ridge crests (Fig. 10d, e).

\section{$<0.8$ Ma reintegration and incision}

Deposition in the Casa Grande basin ceased after $\sim 0.8 \mathrm{Ma}$ (age of an ash $2 \mathrm{~m}$ below the top of southern measured section), and incision likely followed soon after. A pulse of filling followed by incision also occurred in the Humahuaca basin around this time, as recorded by fill terraces up to $300-\mathrm{m}$-thick containing ashes dated to $0.9-$ $0.8 \mathrm{Ma}$. If the Casa Grande basin also experienced a pulse of sediment accumulation at that time, this enhanced flux could have allowed the fill to overtop the barrier at the outlet of the basin and re-establish fluvial connectivity between the Casa Grande and Humahuaca basins (Fig. 13f). This overflow would have increased the tools available to erode the bed along the steepened bedrock channel portion of the Río Yacoraite through the deformed Sierra Alta, thereby allowing a wave of incision to propagate across the Sierra Alta into the Casa Grande basin.

With the re-establishment of fluvial connectivity, post0.8-Ma incision in the Humahuaca basin following terrace abandonment could propagate upstream into the Casa Grande basin (Fig. 13g). The final $\sim 200 \mathrm{~m}$ of bedrock incision, i.e. incising beneath the lower slope break in the downstream portion of the Río Yacoraite (Fig. 10d, e), was likely driven by incision in the Humahuaca basin. This interpretation is consistent with both preserved straths along the lower Río Yacoraite and the unconformity underlying the $0.8 \mathrm{Ma}$ fill in the Humahuaca: all located $\sim 200 \mathrm{~m}$ above the modern channel.

Given that the re-establishment of fluvial connectivity was key to the incision of the Casa Grande basin fill after $0.8 \mathrm{Ma}$, one might ask why incision did not occur during earlier periods of fluvial connectivity, e.g. at $3 \mathrm{Ma}$. Increasing aridity around $3 \mathrm{Ma}$ (Pingel et al., 2014) and resultant decreases in discharge and stream power may have hindered incision rates from coming into balance with rock uplift at Casa Grande's outlet. A second factor that may have contributed to incision rates outpacing rock-uplift rates at $\sim 0.8 \mathrm{Ma}$ is that faulting in the $\mathrm{Hu}-$ mahuaca valley had shifted farther east by that time (Fig. 10), which could have resulted in decreased rates of rock uplift in the Sierra Alta.

\section{Regional context}

Although individual events in the Casa Grande basin history can be explained by climatically driven changes in sediment supply (e.g. basin isolation) or the upstream response to base-level change in the Humahuaca basin (e.g. final incision through the fill), more generally, PlioPleistocene sediment accumulation in the Casa Grande basin was driven by uplift of the Sierra Alta. This phase of renewed uplift, which also included deformation within the Humahuaca basin and uplift of the Tilcara ranges (Pingel et al., 2013, 2014), occurred from $>4.3 \mathrm{Ma}$ until $<1.7 \mathrm{Ma}$. This episode of range building occurred several million years after the arrival of deformation in this area by the middle Miocene, i.e. by $\sim 14-10 \mathrm{Ma}$ in the Sierra Alta and Sierra Hornocal (Deeken et al., 2005; Siks \& Horton, 2011; Insel et al., 2012).

Much of the surface uplift of the Tilcara ranges occurred during this Plio-Pleistocene phase of deformation (Pingel et al., 2013, 2014) and apatite (U-Th)/He cooling ages around 5.6 Ma from the Sierra Hornocal to the northeast (Reiners et al., 2015) suggest that PlioPleistocene exhumation was also significant in these ranges. In the Sierra Alta, on the other hand, both midMiocene apatite fission-track cooling ages (Deeken et al., 2005; Insel et al., 2012) and the topographical constraints on incision along the Rio Yacoraite (Fig. 10), which suggest $<600 \mathrm{~m}$ of Plio-Pleistocene surface uplift, imply lower rock-uplift rates in the Sierra Alta than in the Tilcara ranges. Perhaps climate and sediment supply played such an important role in the Plio-Pleistocene evolution of the Casa Grande basin because deformation rates in the Sierra Alta were relatively low. That this later phase of deformation produced relatively minor uplift of the Sierra Alta may also explain why the rates of sediment accumulation in the Casa Grande basin are nearly an order of magnitude lower than in the $\mathrm{Hu}-$ mahuaca basin and other intermontane basins in the Eastern Cordillera (e.g. Bossi et al., 2001; BywaterReyes et al., 2010; Galli et al., 2014; Schoenbohm et al., 2015).

The higher rates of sediment accumulation in the $\mathrm{Hu}-$ mahuaca basin are probably primarily due to higher rockuplift rates in the Tilcara ranges compared to the Sierra Alta and secondarily to additional accommodation created in the footwall of thrust faults on the west side of the basin. In the Casa Grande basin, which lacked active basin-bounding faults, accommodation was generated solely by the uplift of the downstream barrier (e.g. Fig. 1b). Furthermore, this type of accommodation is temporary: once uplift ceases downstream, the channel should adjust to a lower channel slope, incising through the basin fill. Indeed, a large fraction of the fill in both the Casa Grande and Humahuaca basins has already been removed.

\section{CONCLUSIONS}

Comparison of the timing of events at the 100-kyr timescale between the Casa Grande basin and the neighbouring downstream Humahuaca basin allows discrimination between local controls on basin evolution that affect each 
basin independently and regional controls that result in synchronous events in both basins. Furthermore, detrital zircon provenance of sediment in the Humahuaca basin records changes in its fluvial connectivity with the Casa Grande basin. By integrating stratigraphical analysis of intermontane basin fill, provenance data, sediment-accumulation rates, observations of cross-cutting relationships that constrain the timing of deformation along bounding ranges and topographical evidence of incision history, we are able to assess the controls on the initial onset of deposition, sediment-accumulation rate, basin isolation, reintegration of the fluvial network and subsequent incision. The main conclusions of this study include the following:

1 The 120-m-thick Plio-Pleistocene sedimentary fill in the intermontane Casa Grande basin was deposited between 3.8 and $0.8 \mathrm{Ma}$. The dominantly fluvial strata aggraded in response to local surface uplift at the outlet of the basin as rock uplift in the Sierra Alta outpaced the rate of channel incision. Rock uplift of the Sierra Alta was accommodated along east-vergent thrust faults that were active from $>4.3 \mathrm{Ma}$ to $<1.7 \mathrm{Ma}$ on the west side of the Humahuaca basin. Following reintegration of the fluvial network at $\sim 0.8 \mathrm{Ma}$, the river incised $>150 \mathrm{~m}$ through the Plio-Pleistocene fill and the underlying Casa Grande Formation.

2 Along a given reach of a river system, aggradation or incision may be controlled by regional or local processes. The synchronous return to deposition above a widespread unconformity around $4 \mathrm{Ma}$ in both basins suggests regional forcing, which we attribute to a hypothesized increase in sediment supply in response to enhanced precipitation in the early stages of range uplift and/or increased uplift rates in the Sierra Alta and Tilcara ranges. On the other hand, asynchronous changes in sediment-accumulation rates are locally controlled. In the Humahuaca basin, sediment-accumulation rates nearly double (from 330 to $540 \mathrm{~m} \mathrm{Myr}^{-1}$ ) around $2.5 \mathrm{Ma}$, although in the Casa Grande basin, rates are halved (from 68 to $35 \mathrm{~m} \mathrm{Myr}^{-1}$ ) around $3 \mathrm{Ma}$.

3 To discriminate between basin isolation or sustained fluvial connectivity, well-preserved stratigraphical sections with robust temporal frameworks, reliable provenance data and distinct sedimentary facies are commonly required. However, as is the case in the Casa Grande basin, lacustrine facies associated with basin isolation may be limited in lateral extent and located close to the basin outlet, where preservation potential is low during dissection of the basin following reintegration of the fluvial network. Thus, the provenance of the sediment deposited downstream from the basin can underpin successful identification of periods of basin isolation, as such provenance data will indicate the loss of distinctive source areas located within the catchment area of the basin. Detrital zircon provenance data indicate that fluvial connectivity between the Casa Grande basin and the Humahuaca basin persisted at $3 \mathrm{Ma}$, but by $2.1 \mathrm{Ma}$, the Casa Grande basin became isolated from the downstream drainage system and remained isolated until at least $1.7 \mathrm{Ma}$ and possibly until $0.8 \mathrm{Ma}$.

4 By comparing relative changes in the amount of sediment transported out of the Casa Grande basin to sediment-accumulation rates in the Casa Grande basin, we conclude that basin isolation was accompanied by a decrease in sediment supply to the basin. Given independent evidence for a shift from humid to semi-arid conditions in the Humahuaca basin around this time (Reguero et al., 2007; Pingel et al., 2014), we argue that aridity decreased sediment supply to the point that aggradation was no longer able to keep pace with local surface uplift at the outlet of the Casa Grande basin, resulting in basin isolation.

\section{ACKNOWLEDGEMENTS}

We thank Kate Zeiger, Luke Merrill and Justin LaForge for their assistance with fieldwork and Sarah Slotznick, Steven Skinner, and Joe Kirschvink at the Caltech Paleomagnetics Lab for lab access and support with paleomagnetic measurements. We thank Barbara Carrapa, Delores Robinson and Brian Horton for their constructive reviews. This research was supported by the National Science Foundation through a research grant to D. Burbank under grant 0838265 and via a Graduate Research Fellowship to R. Streit. M. Strecker was supported by Deutsche Forschungsgemeinschaft (DFG) under grant 373/21-1.

\section{CONFLICT OF INTEREST}

No conflict of interest declared.

\section{SUPPORTING INFORMATION}

Additional Supporting Information may be found in the online version of this article:

Table S1. U-Pb geochronology data.

Table S2. Magnetostratigraphy data.

Table S3. Detrital zircon LA-ICPMS U-Pb data.

Table S4. Effect of basin geometry on sedimentaccumulation rate, under constant sediment flux.

\section{REFERENCES}

Amidon, W.H., Luna, L.V., Fisher, G.B., Burbank, D.W., KyLander-Clark, A.R.C. \& Alonso, R. (2015) Provenance and tectonic implications of Orán Group foreland basin sediments, Río Iruya canyon, NW Argentina (23ㅇ). Basin Res., doi: $10.1111 /$ bre. 12139 . 


\section{R.L. Streit et al.}

Barros, A.P., Kim, G., Williams, E. \& Nesbitt, S.W. (2004) Probing orographic controls in the Himalayas during the monsoon using satellite imagery. Nat. Hazard. Earth Syst. Sci., 4, 29-51.

Boll, A. \& HERnáNDEZ, R.M. (1986) Interpretación estructural del área Tres Cruces. Bole. Inform. Petrol., 3, 2-14.

Bonorino, G.G. \& Abascal, L.D. (2012) Drainage and baselevel adjustments during evolution of a late Pleistocene piggyback basin, Eastern Cordillera, Central Andes of northwestern Argentina. Geol. Soc. Am. Bull., 124, 1858-1870.

BookHAgen, B. \& STRECKER, M.R. (2008) Orographic barriers, high-resolution TRMM rainfall, and relief variations along the eastern Andes. Geophys. Res. Lett., 35, L06403.

Bookhagen, B. \& Strecker, M.R. (2012) Spatiotemporal trends in erosion rates across a pronounced rainfall gradient: Examples from the southern Central Andes. Earth Planet. Sci. Lett., $327,97-110$.

Bossi, G.E., GeorgiefF, S.M., Gavriloff, I.J.C., Ibanez, L.M. \& Muruaga, C.M. (2001) Cenozoic evolution of the intramontane Santa Maria basin, Pampean Ranges, northwestern Argentina. 7. S. Am. Earth Sci., 14, 725-734.

Burbank, D.W. (2002) Rates of erosion and their implications for exhumation. Mineral. Mag., 66, 25-52.

BurbanK, D.W. \& RaYNolds, R.G.H. (1988) Stratigraphic keys to the timing of thrusting in terrestrial foreland basins: applications to the Northwestern Himalaya. In: Nem Perspectives in Basin Analysis (Ed. by K.L. Kleinspehn \& C. Paola), pp. 331351. Springer-Verlag, New York.

Burbank, D., Meigs, A. \& Brozovic, N. (1996) Interactions of growing folds and coeval depositional systems. Basin Res., 8, 199-223.

Burbank, D.W., Bookhagen, B., Gabet, E.J. \& Putkonen, J. (2012) Modern climate and erosion in the Himalaya. C.R. Geosci, 344, 610-626.

Bywater-Reyes, S., Carrapa, B., Clementz, M. \& SchoenboHM, L. (2010) Effect of late Cenozoic aridification on sedimentation in the Eastern Cordillera of northwest Argentina (Angastaco basin). Geology, 38, 235-238.

Canavan, R.R., Carrapa, B., Clementz, M.T., Quade, J., DeCelles, P.G. \& Schoenbohm, L.M. (2014) Early Cenozoic uplift of the Puna Plateau, Central Andes, based on stable isotope paleoaltimetry of hydrated volcanic glass. Geology, 42, 447-450.

Carrapa, B. \& DeCelles, P.G. (2015) Regional exhumation and kinematic history of the Central Andes in response to cyclical orogenic processes. Geol. Soc. Am. Mem., 212, 201-213.

Carrapa, B., Strecker, M.R. \& Sobel, E.R. (2006) Cenozoic orogenic growth in the Central Andes: evidence from sedimentary rock provenance and apatite fission track thermochronology in the Fiambala Basin, southernmost Puna Plateau margin (NW Argentina). Earth Planet. Sci. Lett., 247, 82-100.

Carrapa, B., Hauer, J., Schoenbohm, L., Strecker, M.R., Schmitt, A.K., Villanueva, A. \& Gomez, J.S. (2008) Dynamics of deformation and sedimentation in the northern Sierras Pampeanas: an integrated study of the Neogene Fiambala basin, NW Argentina. Geol. Soc. Am. Bull., 120, 15181543.

Carrapa, B., Huntington, K.W., Clementz, M., Quade, J., Bywater-Reyes, S., Schoenbohm, L.M. \& Canavan, R.R. (2014) Uplift of the Central Andes of NW Argentina associated with upper crustal shortening, revealed by multiproxy isotopic analyses. Tectonics, 33, 2013 TC003461.
Cottle, J.M., Kylander-Clark, A.R. \& Vrijmoed, J.C. (2012) $\mathrm{U}-\mathrm{Th} / \mathrm{Pb}$ geochronology of detrital zircon and monazite by single shot laser ablation inductively coupled plasma mass spectrometry (SS-LA-ICPMS). Chem. Geol., 332, 136-147.

Coutand, I., Cobbold, P.R., de Urreiztieta, M., Gautier, P., Chauvin, A., Gapais, D., Rossello, E.A. \& Lopez-Gamundi, O. (2001) Style and history of Andean deformation, Puna plateau, Northwestern Argentina. Tectonics, 20, 210-234.

Coutand, I., Carrapa, B., Deeken, A., Schmitt, A.K., Sobel, E.R. \& STRECKeR, M.R. (2006) Propagation of orographic barriers along an active range front: insights from sandstone petrography and detrital apatite fission-track thermochronology in the intramontane Angastaco basin, NW Argentina. Basin Res., 18, 1-26.

Cristiani, C., Matteini, M., Mazzuoli, R., Omarini, R. \& VILLA, I.M. (2005) Petrology of Late Jurassic-Early Cretaceous Tusaquillas and Abra Laite-Aguilar Plutonic complexes (Central Andes, $23^{\circ} 05^{\prime} \mathrm{S}-66^{\circ} 05^{\prime} \mathrm{W}$ ): a comparison with the rift-related magmatism of NW Argentina and E Bolivia. In: Mesozoic to Cenozoic Alkaline Magmatism in the Brazilian Plataform (Ed. by P. Comin-Chiaramonti \& C. Barros Gomez), pp. 213-241. Editora da Universidade de São Paulo, São Paulo, Brazil.

Crowley, J.L., Schoene, B. \& Bowring, S.A. (2007) U-Pb dating of zircon in the Bishop Tuff at the millennial scale. Geology, 35, 1123-1126.

DeCelles, P.G., Carrapa, B., Horton, B.K. \& Gehrels, G.E. (2011) Cenozoic foreland basin system in the central Andes of Northwestern Argentina: implications for Andean geodynamics and modes of deformation. Tectonics, 30, TC6013.

Deeken, A., Sobel, E.R., Haschke, M. \& Riller, U. (2005) Age of initiation and growth pattern of the Puna plateau, NW Argentina, constrained by AFT thermochronology. Potsdam, Germany Abstract Volume, Terra Nostra, 5 (1), 39.

Deeken, A., Sobel, E.R., Coutand, I., Haschke, M., Riller, U. \& STRECKER, M.R. (2006) Development of the southern Eastern Cordillera, NW Argentina, constrained by apatite fission track thermochronology: from early Cretaceous extension to middle Miocene shortening. Tectonics, 25, TC6003.

Echavarria, L., Hernandez, R., Allmendinger, R. \& ReyNOLDS, J. (2003) Subandean thrust and fold belt of Northwestem Argentina: geometry and timing of the Andean evolution. AAPG Bull., 87, 965-985.

Elger, K., Oncken, O. \& Glodny, J. (2005) Plateau-style accumulation of deformation: Southern Altiplano. Tectonics, 24, TC4020.

Gabaldón, V., M.A. GonZalez, M.A. \& Lizuain, A. (1998) El mapa geológico. In: Estudio geológico integrado de la Quebrada de Humahuaca. (Ed. by V. Gabaldón \& O. Lapido) Servicio Geológico Minero Argentino (SEGEMAR), Anales 30, Buenos Aires.

Galewsky, J. (2009) Rain shadow development during the growth of mountain ranges: an atmospheric dynamics perspective. 7. Geophys. Res. Earth Surf., 114, F01018.

Galli, C.I., Coira, B., Alonso, R., Reynolds, J., Matteini, M. \& Hauser, N. (2014) Tectonic controls on the evolution of the Andean Cenozoic foreland basin: evidence from fluvial system variations in the Payogastilla Group, in the Calchaquí, Tonco and Amblayo Valleys, NW Argentina. 7. S. Am. Earth Sci., 52, 234-259.

Gehrels, G.E., Valencia, V.A. \& Ruiz, J. (2008) Enhanced precision, accuracy, efficiency, and spatial resolution of $\mathrm{U}-\mathrm{Pb}$ 
ages by laser ablation-multicollector-inductively coupled plasma-mass spectrometry. Geochem. Geophys. Geosyst., 9, Q03017.

Godard, V., Tucker, G.E., Burch Fisher, G., Burbank, D.W. \& Bookhagen, B. (2013) Frequency-dependent landscape response to climatic forcing. Geophys. Res. Lett., 40, 859-863.

Gonzalez, M.A., Pereyra, F., Ramallo, E. \& Tchilingurian, P. (2004) Hoja Geológica 2366-IV, Ciudad Libertador General San Martín, provincias de Jujuy y Salta. Boletín 274, Instituto de Geología y Recursos Minerales, Servicio Geológico Minero Argentino. Buenos Aires, 109.

GubBels, T.L., IsaCKs, B.L. \& FARRar, E. (1993) High-level surfaces, plateau uplift, and foreland development, Bolivian Central Andes. Geology, 21, 695-698.

Hain, M.P., Strecker, M.R., Bookhagen, B., Alonso, R.N., Pingel, H. \& SchmitT, A.K. (2011) Neogene to Quaternary broken foreland formation and sedimentation dynamics in the Andes of NW Argentina (25 degrees S). Tectonics, 30, TC2006.

Hilley, G.E. \& STrecker, M.R. (2005) Processes of oscillatory basin filling and excavation in a tectonically active orogen: Quebrada del Toro Basin, NW Argentina. Geol. Soc. Am. Bull., 117, 887-901.

Hongn, F., del Papa, C., Powell, J., Petrinovic, I., Mon, R. \& Deraco, V. (2007) Middle Eocene deformation and sedimentation in the Puna-Eastern Cordillera transition (23 degrees26 degrees $\mathrm{S}$ ): control by preexisting heterogeneities on the pattern of initial Andean shortening. Geology, 35, 271-274.

Horton, B.K. (2005) Revised deformation history of the Central Andes: inferences from Cenozoic foredeep and intermontane basins of the Eastern Cordillera, Bolivia. Tectonics, 24, TC3011.

Hough, B.G., Garzione, C.N., Wang, Z.C., Lease, R.O., BurBANK, D.W. \& Yuan, D.Y. (2011) Stable isotope evidence for topographic growth and basin segmentation: implications for the evolution of the NE Tibetan Plateau. Geol. Soc. Am. Bull., $123,168-185$.

Humphrey, N.F. \& KonRAD, S.K. (2000) River incision or diversion in response to bedrock uplift. Geology, 28, 43-46.

Insel, N., Grove, M., Haschke, M., Barnes, J.B., Schmitt, A.K. \& Strecker, M.R. (2012) Paleozoic to early Cenozoic cooling and exhumation of the basement underlying the eastern Puna plateau margin prior to plateau growth. Tectonics, 31, TC6006.

Jackson, S.E., Pearson, N.J., Griffin, W.L. \& Belousova, E.A. (2004) The application of laser ablation-inductively coupled plasma-mass spectrometry to in situ $\mathrm{U}-\mathrm{Pb}$ zircon geochronology. Chem. Geol., 211, 47-69.

JonEs, C.H. (2002) User-driven integrated software lives: 'Paleomag' paleomagnetics analysis on the Macintosh. Comput. Geosci., 28, 1145-1151.

Jordan, T.E., Isacks, B.L., Allmendinger, R.W., Brewer, J.A., Ramos, V.A. \& Ando, C.J. (1983) Andean tectonics related to geometry of subducted Nazca plate. Geol. Soc. Am. Bull., 94, 341-361.

Jordan, T.E., Flemings, P.B. \& Beers, J.A. (1988) Dating thrust-fault activity by use of foreland-basin strata. In: Nem Perspectives in Basin Analysis (Ed. by K.L. Kleinspehn \& C. Paola), pp. 307-330. Springer-Verlag, New York.

Jordan, T.E., Mrodozis, C., Munoz, N., Blanco, N., Pananont, P. \& Gardeweg, M. (2007) Cenozoic subsurface stratigraphy and structure of the Salar de Atacama Basin, northern Chile. F. S. Am. Earth Sci., 23, 122-146.
Kirschvink, J.L. (1980) The least-squares line and plane and the analysis of paleomagnetic data. Geophys. 7. Roy. Astron. Soc., 62, 699-718.

Kirschvink, J.L., Kopp, R.E., Raub, T.D., Baumgartner, C.T. \& Holt, J.W. (2008) Rapid, precise, and high-sensitivity acquisition of paleomagnetic and rock-magnetic data: development of a low-noise automatic sample changing system for superconducting rock magnetometers. Geochem. Geophys. Geosyst., 9, Q05Y01.

Kleinert, K. \& Strecker, M.R. (2001) Climate change in response to orographic barrier uplift: paleosol and stable isotope evidence from the late Neogene Santa Maria basin, Northwestern Argentina. Geol. Soc. Am. Bull., 113, 728-742.

Lease, R.O., Burbank, D.W., Hough, B., Wang, Z.C. \& Yuan, D.Y. (2012) Pulsed Miocene range growth in northeastern Tibet: insights from Xunhua Basin magnetostratigraphy and provenance. Geol. Soc. Am. Bull., 124, 657-677.

Lisiecki, L.E. \& Raymo, M.E. (2005) A Pliocene-Pleistocene stack of 57 globally distributed benthic delta O-18 records. Paleoceanography, 20, PA1003.

Lourens, L., Hilgen, F., Shackleton, N.J., Laskar, J. \& Wilson, D. (2004) The neogene period. In: A Geologic Time Scale 2004 (Ed. by F.M. Gradstein, J.G. Ogg \& A. Smith), pp. 409-440. Cambridge University Press, Cambridge, UK.

Ludwig, K.R. (2012) User's Manual for Isoplot 3.75, A Geochronological Toolkit for Microsoft Excel. Berkeley Geochronology Center Special Publication No. 5.

Marrett, R. \& Strecker, M.R. (2000) Response of intracontinental deformation in the central Andes to late Cenozoic reorganization of South American Plate motions. Tectonics, 19, 452-467.

Marrett, R.A., Allmendinger, R.W., Alonso, R.N. \& Drake, R.E. (1994) Late Cenozoic tectonic evolution of the Puna Plateau and adjacent foreland, northwestern Argentine Andes. $\mathcal{F}$. S. Am. Earth Sci., 7, 179-207.

Marshall, L.G., Butler, R.F., Drake, R.E. \& Curtis, G.H. (1982) Geochronology of type uquian (late Cenozoic) land mammal age, Argentina. Science, 216, 986-989.

McFadden, P.L. \& McElhinny, M.W. (1990) Classification of the reversal test in paleomagnetism. Geophys. F. Int., 103, 725-729.

Montero-López, C., Strecker, M.R., Schildgen, T.F., Hongn, F., Guzmán, S., Bookhagen, B. \& Sudo, M. (2014) Local high relief at the southern margin of the Andean plateau by 9 Ma: evidence from ignimbritic valley fills and river incision. Terra Nova, 26, 454-460.

Moreno, J.A. (1970) Estratigrafía y paleogeografía del Cretacico superior en la Cuenca del Noroeste Argentino, con especial mencion de los Subgrupos Balbuena y Santa Barbara. Rev. Asoc. Geol. Argent., 25, 9-44.

Mortimer, E., Carrapa, B., Coutand, I., Schoenbohm, L., SoBEL, E.R. \& Gomez, J.S. (2007) Fragmentation of a foreland basin in response to out-of-sequence basement uplifts and structural reactivation: El Cajon-Campo del Arenal basin, NW Argentina. Geol. Soc. Am. Bull., 119, 637-653.

O'Reilly, W. (1984) Rock and Mineral Magnetism. Blackie \& Son, Glasgow.

Paton, C., Woodhead, J.D., Hellstrom, J.C., Hergt, J.M., Greig, A. \& MAAS, R. (2010) Improved laser ablation U$\mathrm{Pb}$ zircon geochronology through robust downhole fractionation correction. Geochem. Geophys. Geosyst., 11, Q0AA06. 


\section{R.L. Streit et al.}

Pearson, D.M., Kapp, P., DeCelles, P.G., Reiners, P.W., Gehrels, G.E., Ducea, M.N. \& Pullen, A. (2013) Influence of pre-Andean crustal structure on Cenozoic thrust belt kinematics and shortening magnitude: Northwestern Argentina. Geosphere, 9, 1766-1782.

Pingel, H., Strecker, M.R., Alonso, R.N. \& Schmitt, A.K. (2013) Neotectonic basin and landscape evolution in the Eastern Cordillera of NW Argentina, Humahuaca Basin (similar to 24 degrees S). Basin Res., 25, 554-573.

Pingel, H., Alonso, R.N., Mulch, A., Rohrmann, A., Sudo, M. \& Strecker, M.R. (2014) Pliocene orographic barrier uplift in the southern Central Andes. Geology, 42, 691-694.

Quade, J., Dettinger, M.P., Carrapa, B., DeCelles, P., Murray, K.E., Huntington, K.W., Cartwright, A., Canavan, R.R., Gehrels, G. \& Clementz, M. (2015) The growth of the central Andes, $22^{\circ} \mathrm{S}-26^{\circ} \mathrm{S}$. Geol. Soc. Am. Mem., 212, 277-308.

Ramos, V.A. (1999) Los depósitos sinorogénicos Terciarios de la región Andina. In: Geología Argentina (Ed. by R. Caminos.), Anales, 29, 651-682. Instituto de Geologi'a y Recursos Minerales, Buenos Aires, Argentina.

Reguero, M.A., Candela, A.M. \& Alonso, R.N. (2007) Biochronology and biostratigraphy of the Uquia Formation (Pliocene-early Pleistocene, NW Argentina) and its significance in the Great American Biotic Interchange. 7. S. Am. Earth Sci., 23, 1-16.

Reiners, P.W., Thomson, S.N., Vernon, A., Willett, S.D., Zattin, M., Einhorn, J., Gehrels, G., Quade, J., Pearson, D., Murray, K.E. \& Cavazza, W. (2015) Low-temperature thermochronologic trends across the central Andes, $21^{\circ} \mathrm{S}-$ $28^{\circ}$ S. Geol. Soc. Am. Mem., 212, 215-249.

Reynolds, J.H., Galli, C.I., Hernandez, R.M., Idleman, B.D., Kotila, J.M., Hilliard, R.V. \& NaEser, C.W. (2000) Middle Miocene tectonic development of the Transition Zone, Salta Province, northwest Argentina: magnetic stratigraphy from the Metan Subgroup, Sierra de Gonzalez. Geol. Soc. Am. Bull., 112, 1736-1751.

Reynolds, J.H., Hernandez, R.M., Galli, C.I. \& Idleman, B.D. (2001) Magnetostratigraphy of the Quebrada La Porcelana section, Sierra de Ramos, Salta Province, Argentina: age limits for the Neogene Oran Group and uplift of the southern Sierras Subandinas. 7. S. Am. Earth Sci., 14, 681-692.

Rodríguez Fernández, L.R., Heredia, N., Seggiaro, R.E. \& GonzÁLEZ, M.A. (1999) Estructura andina de la Cordillera Oriental en el área de la Quebrada de Humahuaca, provincia de Jujuy, NO de Argentina. Trabajo. Geol. Univ. Oviedo, 21, 321-332.

Rohrmann, A., Strecker, M.R., Bookhagen, B., Mulch, A., Sachse, D., Pingel, H., Alonso, R.N., Schildgen, T.F. \& Montero, C. (2014) Can stable isotopes ride out the storms? The role of convection for water isotopes in models, records, and paleoaltimetry studies in the central Andes. Earth Planet. Sci. Lett., 407, 187-195.

Salfity, J.A., Brandán, E.M., Monaldi, C.R. \& Gallardo, E.F. (1984) Tectónica compresiva cuaternaria en la Cordillera Oriental Argentina, latitud de Tilcara (Jujuy). Acta IX Congr. Geol. Argent., 2, 427-434.

Sancho, C., Pena, J.L., Rivelli, F., Rhodes, E. \& Munoz, A. (2008) Geomorphological evolution of the Tilcara alluvial fan (Jujuy Province, NW Argentina): tectonic implications and palaeoenvironmental considerations. F. S. Am. Earth Sci., 26, $68-77$.
Scharer, U. (1984) The effect of initial Th-230 disequilibrium on young $\mathrm{U}-\mathrm{Pb}$ ages - the Makalu case, Himalaya. Earth Planet. Sci. Lett., 67, 191-204.

Schildgen, T.F., Yildirim, C., Cosentino, D. \& Strecker, M.R. (2014) Linking slab break-off, Hellenic trench retreat, and uplift of the Central and Eastern Anatolian plateaus. Earth Sci. Rev., 128, 147-168.

Schoenbohm, L.M., Carrapa, B., McPherson, H.M., Pratt, J.R., Bywater-Reyes, S. \& Mortimer, E. (2015) Climate and tectonics along the southern margin of the Puna Plateau, NW Argentina: origin of the late Cenozoic Punaschotter conglomerates. Geol. Soc. Am. Mem., 212, 251-260.

Siks, B.C. \& Horton, B.K. (2011) Growth and fragmentation of the Andean foreland basin during eastward advance of fold-thrust deformation, Puna plateau and Eastern Cordillera, northern Argentina. Tectonics, 30, TC6017.

SkLar, L.S. \& Dietrich, W.E. (2001) Sediment and rock strength controls on river incision into bedrock. Geology, 29, 1087-1090.

Sobel, E.R. \& STREcker, M.R. (2003) Uplift, exhumation and precipitation: tectonic and climatic control of Late Cenozoic landscape evolution in the Northern Sierras Pampeanas, Argentina. Basin Res., 15, 431-451.

Sobel, E.R., Hilley, G.E. \& Strecker, M.R. (2003) Formation of internally drained contractional basins by aridity-limited bedrock incision. 7. Geophys. Res. Solid Earth, 108, 2344.

Stacey, J.S. \& Kramers, J.D. (1975) Approximation of terrestrial lead isotope evolution by a 2 -stage model. Earth Planet. Sci. Lett., 26, 207-221.

Starck, D. \& Anzótegui, L.M. (2001) The late miocene climatic change - persistence of a climatic signal through the orogenic stratigraphic record in northwestern Argentina. F. S. Am. Earth Sci., 14, 763-774.

Strecker, M.R., Cerveny, P., Bloom, A.L. \& Malizia, D. (1989) Late Cenozoic tectonism and landscape development in the foreland of the Andes: Northern Sierras Pampeanas (26-28 ${ }^{\circ}$ S), Argentina. Tectonics, 8, 517-534.

Strecker, M.R., Alonso, R.N., Bookhagen, B., Carrapa, B., Hilley, G.E., Sobel, E.R. \& Trauth, M.H. (2007) Tectonics and climate of the southern Central Andes. Annu. Rev. Earth Planet. Sci., 35, 747-787.

Strecker, M.R., Alonso, R., Bookhagen, B., Carrapa, B., Coutand, I., Hain, M.P., Hilley, G.E., Mortimer, E., Schoenbohm, L. \& Sobel, E.R. (2009) Does the topographic distribution of the central Andean Puna Plateau result from climatic or geodynamic processes? Geology, 37, 643-646.

Turner, J.C.M. (1960) Estratigrafia de la Sierra de Santa Victoria y adyacencias. Bol. Acad. Nac. Cienc., 41, 163-196.

Turner, J.C.M. \& Méndez, V. (1979) Puna. Segundo simposio de geología regional argentina, Córdoba, Argentina, Academia Nacional de Ciencias Córdoba.

Turner, J.C.M. \& Mon, R. (1979) Cordillera Oriental. Segundo simposio de geología regional argentina, Córdoba, Argentina, Academia Nacional de Ciencias Córdoba.

Uba, C.E., Strecker, M.R. \& Schmitt, A.K. (2007) Increased sediment accumulation rates and climatic forcing in the central Andes during the late Miocene. Geology, 35, 979-982.

Uba, C.E., Kley, J., Strecker, M.R. \& Schmitt, A.K. (2009) Unsteady evolution of the Bolivian Subandean thrust belt: the role of enhanced erosion and clastic wedge progradation. Earth Planet. Sci. Lett., 281, 134-146.

Vera, C., Higgins, W., Amador, J., Ambrizzi, T., Garreaud, R., Gochis, D., Gutzler, D., Lettenmaier, D., Marengo, 
J., Mechoso, C.R., Nogues-Paegle, J., Dias, P.L.S. \& Zhang, C. (2006) Toward a unified view of the American monsoon systems. F. Clim., 19, 4977-5000.

Vermeesch, P. (2012) On the visualisation of detrital age distributions. Chem. Geol., 312, 190-194.

Whitman, D., Isacks, B.L. \& Kay, S.M. (1996) Lithospheric structure and along-strike segmentation of the Central Andean Plateau: seismic Q, magmatism, flexure, topography and tectonics. Tectonophysics, 259, 29-40.

Wiedenbeck, M., Alle, P., Corfu, F., Griffin, W.L., Meier, M., Oberli, F., Vonquadt, A., Roddick, J.C. \& Speigel, W. (1995) Three natural zircon standards for U-Th- $\mathrm{Pb}, \mathrm{Lu}-\mathrm{Hf}$, trace element and REE analysis. Geostandards Newslett., 19, 1-23.

Yildirim, C., Schildgen, T.F., Echtler, H., Melnick, D. \& STRECKER, M.R. (2011) Late Neogene and active orogenic uplift in the Central Pontides associated with the North Anatolian Fault: implications for the northern margin of the Central Anatolian Plateau, Turkey. Tectonics, 30, TC5005.

Zachos, J., Pagani, M., Sloan, L., Thomas, E. \& Billups, K. (2001) Trends, rhythms, and aberrations in global climate 65 Ma to present. Science, 292, 686-693.

Zappettini, E. (1989) Geología y metalogénesis de la región comprendida entre las localidades de Santa Ana y Cobres, provincias de Jujuy y Salta, República Argentina. Tesis doctoral Thesis, Universidad de Buenos Aires, Buenos Aires.

Manuscript received 24 October 2014; In revised form 10 April 2015; Manuscript accepted 29 May 2015. 